\title{
Tracing troposphere-to-stratosphere transport above a mid-latitude deep convective system
}

\author{
M. I. Hegglin ${ }^{1}$, D. Brunner ${ }^{1}$, H. Wernli ${ }^{1}$, C. Schwierz ${ }^{1}$, O. Martius ${ }^{1}$, P. Hoor ${ }^{1}, 3$, H. Fischer ${ }^{3}$, U. Parchatka ${ }^{3}$, \\ N. Spelten ${ }^{2}$, C. Schiller ${ }^{2}$, M. Krebsbach ${ }^{2}$, U. Weers ${ }^{1}$, J. Staehelin ${ }^{1}$, and Th. Peter ${ }^{1}$ \\ ${ }^{1}$ Institute for Atmospheric and Climate Science, Swiss Federal Institute of Technology, Zürich, Switzerland \\ ${ }^{2}$ Institute of Chemistry and Dynamics of the Geosphere, ICG-I, Research Centre Jülich, Germany \\ ${ }^{3}$ Max Planck Institute for Chemistry, Mainz, Germany
}

Received: 10 December 2003 - Published in Atmos. Chem. Phys. Discuss.: 14 January 2004

Revised: 21 April 2004 - Accepted: 6 May 2004 - Published: 18 May 2004

\begin{abstract}
Within the project SPURT (trace gas measurements in the tropopause region) a variety of trace gases have been measured in situ in order to investigate the role of dynamical and chemical processes in the extra-tropical tropopause region. In this paper we report on a flight on 10 November 2001 leading from Hohn, Germany $\left(52^{\circ} \mathrm{N}\right)$ to Faro, Portugal $\left(37^{\circ} \mathrm{N}\right)$ through a strongly developed deep stratospheric intrusion. This streamer was associated with a large convective system over the western Mediterranean with potentially significant troposphere-to-stratosphere transport. Along major parts of the flight we measured unexpectedly high $\mathrm{NO}_{\mathrm{y}}$ mixing ratios. Also $\mathrm{H}_{2} \mathrm{O}$ mixing ratios were significantly higher than stratospheric background levels confirming the extraordinary chemical signature of the probed air masses in the interior of the streamer. Backward trajectories encompassing the streamer enable to analyze the origin and physical characteristics of the air masses and to trace troposphere-to-stratosphere transport. Near the western flank of the streamer features caused by long range transport, such as tropospheric filaments characterized by sudden drops in the $\mathrm{O}_{3}$ and $\mathrm{NO}_{y}$ mixing ratios and enhanced $\mathrm{CO}$ and $\mathrm{H}_{2} \mathrm{O}$ can be reconstructed in great detail using the reverse domain filling technique. These filaments indicate a high potential for subsequent mixing with the stratospheric air. At the south-western edge of the streamer a strong gradient in the $\mathrm{NO}_{y}$ and the $\mathrm{O}_{3}$ mixing ratios coincides very well with a sharp gradient in potential vorticity in the ECMWF fields. In contrast, in the interior of the streamer the observed highly elevated $\mathrm{NO}_{y}$ and $\mathrm{H}_{2} \mathrm{O}$ mixing ratios up to a potential temperature level of $365 \mathrm{~K}$ and potential vorticity values of maximum 10 PVU cannot be explained in terms of resolved troposphere-to-stratosphere transport along the backward trajectories. Also mesoscale simulations with a High Resolution Model reveal no direct evidence for convective
\end{abstract}

Correspondence to: M. I. Hegglin

(michaela.hegglin@env.ethz.ch)
$\mathrm{H}_{2} \mathrm{O}$ injection up to this level. Elevated $\mathrm{H}_{2} \mathrm{O}$ mixing ratios in the ECMWF and HRM are seen only up to about tropopause height at $340 \mathrm{hPa}$ and $270 \mathrm{hPa}$, respectively, well below flight altitude of about $200 \mathrm{hPa}$. However, forward tracing of the convective influence as identified by satellite brightness temperature measurements and counts of lightning strokes shows that during this part of the flight the aircraft was closely following the border of an air mass which was heavily impacted by convective activity over Spain and Algeria. This is evidence that deep convection at mid-latitudes may have a large impact on the tracer distribution of the lowermost stratosphere reaching well above the thunderstorms anvils as claimed by recent studies using cloud-resolving models.

\section{Introduction}

Reactive nitrogen $\left(\mathrm{NO}_{\mathrm{y}}\right)$ has a pivotal influence on the ozone chemistry of the troposphere and the stratosphere. While in the stratosphere (above 18 to $20 \mathrm{~km}$ height) nitrogen oxides $\left(\mathrm{NO}_{\mathrm{x}}=\mathrm{NO}+\mathrm{NO}_{2}\right)$ destroy ozone in a catalytic cycle and therefore contribute to ozone depletion (IPCC, 1999), in the troposphere they act together with hydrocarbons and carbon monoxide (CO) as important precursors of ozone formation. Also for the lowermost stratosphere (LMS), the region between the tropopause and the $380 \mathrm{~K}$ potential temperature surface (Holton et al., 1995), numerical simulations show that nitrogen oxides tend to enhance $\mathrm{O}_{3}$ mixing ratios (IPCC, 1999). Furthermore, $\mathrm{O}_{3}$ represents a strong greenhouse gas in the tropopause region and an increase in $\mathrm{O}_{3}$ mixing ratios at this altitude may have significant influence on the radiative forcing and hence on surface temperatures (Lacis et al., 1990; Forster and Shine, 1997). Likewise water vapor in the upper troposphere and lower stratosphere has important radiative and chemical effects (Oltmans and Hofmann, 1995). Nevertheless, for both stratospheric $\mathrm{O}_{3}$ as well as for $\mathrm{H}_{2} \mathrm{O}$ 
there is considerable uncertainty concerning their trends in the tropopause region (IPCC, 2001).

The budget of $\mathrm{NO}_{\mathrm{y}}$ in the LMS is largely determined by its main source, the downward transport from the lower stratosphere, where odd nitrogen is produced through the reaction between $\mathrm{N}_{2} \mathrm{O}$ and $\mathrm{O}\left({ }^{1} \mathrm{D}\right)$ (Brasseur and Solomon, 1986). Other sources may be transport from the extratropical troposphere along isentropic surfaces (Hoerling et al., 1993; Dessler et al., 1995; Dethof et al., 2000) and convective injection in overshooting thunderclouds (Poulida et al., 1996; Ström et al., 1999). This tropospheric air may be enriched in $\mathrm{NO}_{\mathrm{y}}$ through production of $\mathrm{NO}$ by lightning or upward transport of polluted air from the planetary boundary layer. Also, sedimentation of polar stratospheric cloud particles in the polar vortex can lead to redistribution of $\mathrm{NO}_{\mathrm{y}}$ and a nitrification of the LMS down to altitudes as low as 10-12.5 km (Fischer et al., 1997; Koike et al., 2002). In addition, aircraft may directly emit $\mathrm{NO}_{\mathrm{x}}$ into the LMS. Estimates suggest that $20-40 \%$ of total current aircraft emissions are released in the LMS (Hoinka et al., 1993; Schumann, 1997). While emissions by aircraft are well quantified, large uncertainties remain concerning the source strength of $\mathrm{NO}_{\mathrm{x}}$ by lightning (Lee et al., 1997) or the importance of deep convective events at mid-latitudes (IPCC, 1999). Levizzani and Setvak (1996) first reported on distinct plume features visible as cirrus cloud layers above the anvil of convective storms in images from the Advanced Very High Resolution Radiometer (AVHRR) on NOAA polar orbiting satellites. Recent modelstudies by Mullendore (personal communication, 2003) and Wang (2003) show that the breaking of gravity waves at the top of deep convective systems in mid-latitudes can cause injection of water vapor and other tropospheric tracers into the lowermost stratosphere in the form of plumes well above the thunderstorm anvils. Experimental evidence for the introduction of aerosols from forest fire smoke into the lower stratosphere has been given by aircraft measurements during the STREAM II campaign (Waibel et al., 1999) and by POAM satellite observations (Fromm et al., 2000). Another mechanism for cross-tropopause mixing is described by Zierl and Wirth (1997) where radiation causes a sinking of the tropopause in upper tropospheric anticyclones leading to a net troposphere-to-stratosphere mass flux. This again may lead to an enhancement of the $\mathrm{NO}_{\mathrm{y}}$ mixing ratio in the lowermost stratosphere as $\mathrm{NO}_{\mathrm{y}}$ mixing ratios in the upper troposphere at mid-latitudes are higher than in the tropics (Fischer et al., 2000). Finally, $\mathrm{NO}_{\mathrm{y}}$ is a chemically long-lived tracer in the stratosphere, and stratosphere-to-troposphere transport (STT) represents the main sink of $\mathrm{NO}_{\mathrm{y}}$ from the stratosphere.

The composition of the lowermost stratosphere changes with season and location and is mainly influenced by the relative importance between residual-mean downward transport from the stratospheric overworld above $380 \mathrm{~K}$ and upward transport from the troposphere across the extratropical tropopause. Further investigations are needed to quantify the amount of tropospheric air transported into the LMS by convective activity as opposed to isentropic transport and how this alters the chemical composition and in particular the $\mathrm{NO}_{\mathrm{y}}$ mixing ratios of the LMS.

In this paper we present a case study providing experimental evidence that troposphere-to-stratosphere transport (TST) caused by mid-latitude intense thunderstorms is able to strongly influence the chemical composition of the lowermost stratosphere. These findings tie in with the results by Fischer et al. (2003) showing injection of boundary layer air into the LMS by deep convection during the MINOS campaign and by Poulida et al. (1996) on the observations of extensive stratosphere-troposphere exchange (STE) within an intense mid-latitude thunderstorm over North Dakota. In the project SPURT (trace gas transport in the tropopause region) high resolution in-situ measurements of a variety of chemical tracers were performed in order to investigate their distribution and seasonal variability and to gain better insight into the role of dynamical and chemical processes shaping the tropopause region. We focus on the measurements obtained during the SPURT mission flight on 10 November 2001 leading through a spectacularly deep stratospheric intrusion which developed over south-western Europe on that day. The whole episode from 4 to 19 November was very active in terms of meteorological phenomena over the North Atlantic and triggered a number of other investigations. For instance Stohl et al. (2003) reported on fast transport of air pollution from North America to Europe supported by an explosive cyclogenesis near Greenland on 7 to 11 November as traced by GOME satellite observations of $\mathrm{NO}_{2}$ and simulated using a trajectory parcel model. Thomas et al. (2003) analyzed a severe weather event over Spain and Algeria and its impact on the distributions on $\mathrm{O}_{3}$ and $\mathrm{NO}_{2}$ using combined GOME $\mathrm{NO}_{2}$ observations and simulations of a stratospheric chemical transport model (ROSE), and concluded that about two-third of the total atmospheric content of $\mathrm{NO}_{2}$ was located in the troposphere above cloud levels. Martius et al. (in preparation, $2004^{1}$ ) present a detailed analysis of the dynamical situation and the formation mechanism of the deep stratospheric intrusion.

\section{Chemical measurements}

The data presented in this paper have been measured on 10 November 2001 on a flight from Hohn $\left(52^{\circ} \mathrm{N}\right)$, Germany, to Faro $\left(37^{\circ} \mathrm{N}\right)$, Portugal (see Fig. 1). A Learjet $35 \mathrm{~A}$ which reaches altitudes of up to $13 \mathrm{~km}$ was used as experimental platform. Total reactive nitrogen $\left(\mathrm{NO}_{\mathrm{y}}=\mathrm{NO}+\mathrm{NO}_{2}+\mathrm{NO}_{3}+\mathrm{HNO}_{3}+\mathrm{HNO}_{4}+\mathrm{HONO}\right.$ $+\mathrm{PAN}+\mathrm{RONO}_{2}+\mathrm{ClONO}_{2}+2 * \mathrm{~N}_{2} \mathrm{O}_{5}+\mathrm{BrONO}_{2}+$ organic nitrate + particulate nitrate $(<1 \mu \mathrm{m}))$ was measured by chemiluminescence, by letting $\mathrm{NO}$ react with $\mathrm{O}_{3}$ after reducing $\mathrm{NO}_{\mathrm{y}}$ species to $\mathrm{NO}$ using an externally mounted

\footnotetext{
${ }^{1}$ Martius, O.: A case-study on the dynamical effects of a hurricane upon the downstream evolution, in preparation, 2004.
} 
catalytic gold converter with $\mathrm{CO}$ as reduction agent (Fahey et al., 1985). The converter samples in backward direction in order to exclude particles with diameter $>1 \mu \mathrm{m}$. For technical details of the measuring system see Lange et al. (2002). Previously the measurement system has been implemented successfully on several STREAM campaigns (Fischer et al., 2000).

The conversion efficiency of the analyzer was quantified by three in-flight calibrations with known amounts of $\mathrm{NO}_{2}$ and varied between 90 and 94\%. Similarly, the sensitivity was calibrated twice during the flight by adding known amounts of NO and varied by less than $3.5 \%$. The chemiluminescence detector was switched every $9 \mathrm{~s}$ to pre-chamber mode in order to determine the temporal evolution of the instrument background signal (Ridley and Howlett, 1974). In addition, zero calibrations with synthetic air were performed four times during the flight to determine the temporal evolution of the $\mathrm{NO}_{\mathrm{y}}$ artifact signal which is a common feature in $\mathrm{NO}_{\mathrm{y}}$ measurements. Its origin is not fully understood but is in part due to impurities of the $\mathrm{CO}$ reduction agent $(\mathrm{Fa}-$ hey et al., 1985). Note that the specific design of the converter allows adding all calibration gases upstream of the converter at the inlet tip. The precision of the $\mathrm{NO}_{\mathrm{y}}$ measurement has been determined by the standard-deviation of the in-flight $\mathrm{NO}_{2}$ calibrations to $\pm 8 \%(2 \sigma)$. The accuracy includes the uncertainty of the calibration gas standards $( \pm 4 \%$ $(2 \sigma)$ ), and the uncertainty in the conversion efficiency for different $\mathrm{NO}_{\mathrm{y}}$ species $( \pm 13 \%(2 \sigma))$. During the first flight hour of the flight on 10 November 2001, the overall accuracy was very low $( \pm 50 \%(2 \sigma))$ mainly due to an initial contamination of the converter but improved to the normal level of about $\pm 16 \%(2 \sigma)$ for the rest of the flight. The reason of the contamination and its effect on the background signal have been investigated in detail. A possible reason could have been pollution of the converter through sampling of air and aerosols in the airport environment. This is not likely as the converter is flushed during the ascent phase with synthetic air. The enhanced background was found to result primarily from a startup procedure during takeoff using for security reasons ambient air instead of pure $\mathrm{O}_{2}$ to generate the reaction agent $\mathrm{O}_{3}$. Its influence exhibits an exponential decrease and could be reproduced in laboratory studies. An additional influence on the background signal was also due to the calibration gas $\mathrm{NO}_{2}$ entering the converter accidentally during the ascent phase of the aircraft as well as during zero air and NO calibrations. The influence of this problem and its temporal evolution has been estimated in different tests on subsequent flights. Both contaminations were accounted for in the evaluation of the raw data. The artifact signal is normally determined by linear interpolation of the signals measured between subsequent zero air calibrations. Due to the accidental contaminations an additional not well characterized offset had to be subtracted. By subtracting this signal, modeled as an exponentially decreasing function of time, the zero air calibration values were reduced to the normal level observed on other flights. The uncertainty associated with this procedure was conservatively assumed to be $50 \%$ of the subtracted signal itself and sensitivity tests with other exponential fits showed that corrections larger or smaller than this range would result in an unrealistic background signal level (e.g. lower than pre-chamber mode signals) and/or negative $\mathrm{NO}_{\mathrm{y}}$ concentrations.

$\mathrm{O}_{3}$ was measured by a UV absorption photometer (accuracy $\pm 5 \%$, precision \pm 2.5 ppbv, Mottaghy, 2001), and $\mathrm{H}_{2} \mathrm{O}$ by a Lyman- $\alpha$-Hygrometer with an overall accuracy better than $\pm 5 \%$ (Zöger et al., 1999). $\mathrm{N}_{2} \mathrm{O}$ and $\mathrm{CO}$ data were sampled with a Tunable Diode Laser Absorption Spectrometer (TDLAS) with total uncertainty of the measurements of less than $\pm 2 \%$ (Hoor et al., 2002).

\section{Models and diagnostic methods}

To support the analysis of the observations extensive use was made of trajectory calculations and analyses of meteorological fields from a synoptic-scale global and a mesoscale regional model. The two models and the applied methods are briefly described here.

\subsection{ECMWF data and trajectories}

We used analyses of the European Centre for Medium-Range Weather Forecasts (ECMWF) available on 60 vertical levels from the surface up to $0.01 \mathrm{hPa}$ for the description of the meteorological situation and analysis of the dynamical processes. The 6 hourly analyses were complemented by intermediate 3-h forecasts. Sequences of the three-dimensional wind field were used for the calculation of trajectories with the Lagrangian Analysis Tool (LAGRANTO)(Wernli and Davies, 1997). Several variables characterizing the physical state of the air parcels including temperature, specific humidity and potential vorticity were traced along the trajectory paths.

Four different types of trajectories have been calculated: (i) 10-day backward trajectories were started from the exact location of the aircraft in time and space every $10 \mathrm{sec}$ along the flight path. (ii) For use with the Reverse Domain Filling technique we calculated a total of 1.5 Mio 10-day backward trajectories from a specified grid from three different starting times as explained in Sect. 3.2. (iii) Additional 1.5-day backward trajectories from three distinct levels of the same grid at 200, 250, and $270 \mathrm{hPa}$ and starting times of 09:00 and 12:00 UTC to trace convective influence and (iv) 10-day forward trajectories started from the same grid for starting times of 09:00 and 12:00 UTC.

\subsection{Reverse Domain Filling}

The Reverse Domain Filling technique (RDF)(Schoeberl and Newman, 1995) has been applied in this case study to investigate the three-dimensional fine-scale structure of the 


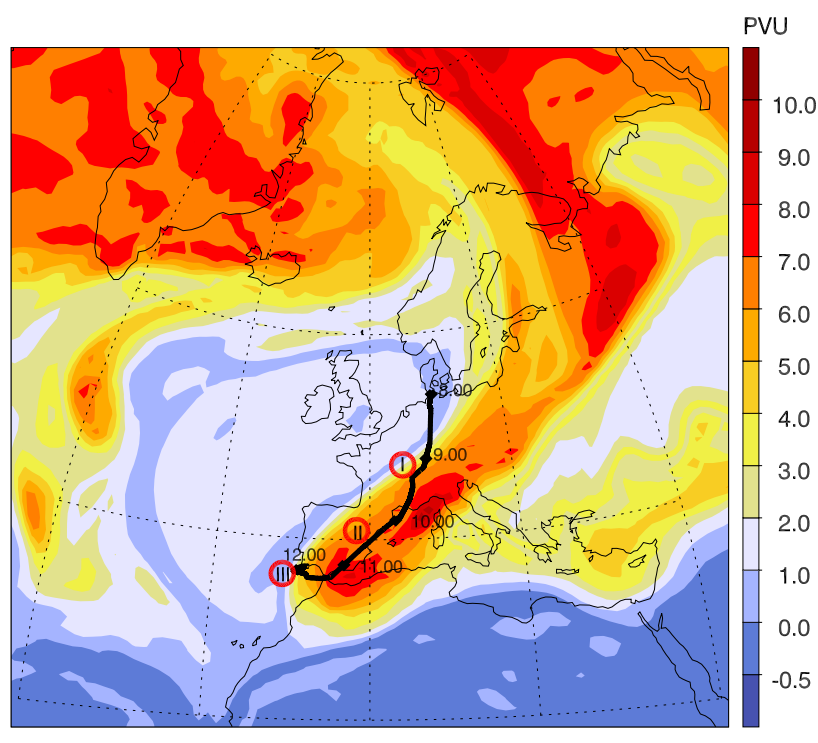

Fig. 1. Flight path from 08:00 to 12:00 UTC, 10 November 2001 (black line) and PV on 230 hPa pressure level at 09:00 UTC (contours). A deep stratospheric intrusion reaches to Northern Africa and to the west a prominent tropospheric ridge extends over the North Atlantic ocean. The streamer was associated with widespread convective activity over the western Mediterranean. The numbers I, II and III refer to different segments of the flight as described in Sect. 5 .

streamer and to trace back the history of air parcels in terms of origin and physical characteristics. The RDF setup involved the following: a 10-day backward trajectory was started from each grid point of a specified grid covering western Europe. The grid box was spanning from $-12^{\circ} \mathrm{E}$ to $+12^{\circ} \mathrm{E}, 30^{\circ} \mathrm{N}$ to $55^{\circ} \mathrm{N}$ and extended in the vertical from 650 to $140 \mathrm{hPa}$. The grid resolution was 25 by $25 \mathrm{~km}$ in the horizontal and $10 \mathrm{hPa}$ in the vertical. The backward trajectory calculations were started at three different times on 10 November, namely 06:00, 09:00 and 12:00 UTC to provide a time development of the reconstructed information. The trajectories can be used to advect a tracer such as PV or specific humidity from an earlier position onto the starting points of the backward trajectories (i.e. the specified grid). Fields of $\mathrm{PV}$ reconstructed in this way will be denoted $\mathrm{rPV}$ in the following and the integration time will also be specified.

\subsection{Climate High Resolution Model}

We performed model runs with the limited-area Climate High Resolution Model (CHRM) as used and validated by Frei et al. (2003) and Vidale et al. (2003) to obtain more highly resolved dynamical information than provided by the ECMWF analyses and in particular to gain better insight in the structure of the deep convective systems over the western Mediterranean and their potential for the production of NO by lightning and subsequent injection of tropospheric air into the LMS. The CHRM's parent model is the High Resolu- tion Model (HRM) of the German Weather Service (DWD). It is a hydrostatic model using Kessler-type (Kessler, 1969) grid-scale cloud microphysics as refined by Lin et. al. (1983) and the mass flux convection scheme after Tiedtke (1989). The model simulations have been initialized by the ECMWF analysis at 00:00 UTC on 9 November 2001 and have been run for $48 \mathrm{~h}$. They were initialized on forty layers between $1010 \mathrm{hPa}$ and $15 \mathrm{hPa}$ in height, with an enhanced density of levels in the tropopause region. The grid-resolution was $0.25^{\circ}$ between $26^{\circ} \mathrm{N}$ to $58^{\circ} \mathrm{N}$ and $21^{\circ} \mathrm{W}$ to $21^{\circ} \mathrm{E}$.

\section{Meteorological situation}

Figure 1 shows the potential vorticity distribution on a hybrid model level corresponding to about $230 \mathrm{hPa}$ on 10 November 2001 as analyzed by ECMWF and the flight track overlaid in black. The whole period from 4 to 19 November spanned a series of remarkable meteorological events. On 4 and 5 November two hurricanes, Michelle and Noel, were located over the western North Atlantic. Strong Rossby wave activity led to significant north-south excursions of air masses. Over the central Atlantic subtropical air masses were advected northwards forming a ridge which extended from the eastern coast of North America to northern Europe. The ridge was fed by diabatic processes associated with several cyclones and the aforementioned hurricanes, and was associated with a particularly strong anticyclonically curved jet stream. Lifting of the tropopause in the ridge and the northward advection of ozone-poor subtropical air (Koch et al., 2002) resulted in an ozone mini-hole on 9 November centered over Scotland with minimum ozone columns of only $190 \mathrm{DU}$ as seen by the GOME instrument (http://www.esa.int/export/esaCP/ ESAHFRQQSTC_index_0.html). To the east of the ridge a Rossby wave is observed to be breaking with both poleward and equatorward components very similar to the meteorological situation on 5 June 2000 described by Bradshaw et al. (2002). The poleward component is seen in Fig. 1 as a thin tropospheric intrusion of low PV extending from Scandinavia up to the northeastern tip of Greenland. The equatorward component is seen as an elongated and deep stratospheric intrusion in the area of the flight path consisting of Arctic air which had moved rapidly from Scandinavia to the Iberian peninsula during the previous two days. Maximum tropopause pressures in the intrusion were as high as $650 \mathrm{hPa}$. This streamer was associated with a surface low that caused severe flooding in Algeria (Thomas et al., 2003). On its forward flank the streamer triggered a series of deep convective storms across the western Mediterranean from the Algerian coast towards Sicily and the Apennines. For a detailed analysis of the dynamical situation and the physical mechanism related to the formation of the streamer see Martius et al. (in preparation, $2004^{2}$ ). On the main part of the flight from

\footnotetext{
${ }^{2}$ Martius, O.: A case-study on the dynamical effects of a hurricane upon the downstream evolution, in preparation, 2004.
} 
Hohn to Faro, the Learjet flew within the streamer reaching $\Theta$-levels up to $365 \mathrm{~K}$ and probing air masses with relatively high potential vorticity (maximum $=10 \mathrm{PVU}$ ). In segment I of the flight (as indicated in Fig. 1) and again briefly before landing (including the air masses of flight segment III), and also on the return flight later on the same day, the aircraft probed the subtropical air masses described above. In flight segment II (between 09:36 and 11:15 UTC), the probed air masses originated from the polar region with maximum PVvalues along the backward trajectories of $12 \mathrm{PVU}$ (for more details see Sect. 5.3).

\section{Results and discussion}

In Fig. 2 time series of the measured trace gases and meteorological quantities during the flight on 10 November 2001 are depicted. Different flight segments are shaded in grey and labeled with numbers I to III. Their geographical position is indicated in Fig. 1. In the following sections we discuss the features in the trace gas measurements of the different flight segments. In Fig. 3a and b, showing the correlations between measured $\mathrm{O}_{3}$ and $\mathrm{NO}_{\mathrm{y}}$ and between $\mathrm{O}_{3}$ and $\mathrm{H}_{2} \mathrm{O}$, respectively, the different characteristics of the air masses of the three segments are clearly distinguishable.

\subsection{Flight-segment I}

The most striking feature in the tracer-measurements is found in the first segment at the entrance to the streamer (label I in Figs. 1, 2 and 3). While flying on a constant pressure level of $215 \mathrm{hPa}$, potential vorticity (Fig. 2d) and potential temperature (not shown) were steadily increasing. However, the concurrent increases in $\mathrm{NO}_{\mathrm{y}}$ and $\mathrm{O}_{3}$ mixing ratios were interrupted three times by sudden drops. Mixing ratios of $\mathrm{NO}_{\mathrm{y}}$ decreased from 1.3, 3.3 and $3.6 \mathrm{ppbv}$ to $0.9,1.4$ and $1.1 \mathrm{ppbv}$, while $\mathrm{O}_{3}$ mixing ratios decreased from 150 , 250 , and $320 \mathrm{ppbv}$ to values of 90,120 , and $130 \mathrm{ppbv}$, respectively. The second and third drop were accompanied by simultaneous increases in the $\mathrm{CO}$ mixing ratio by about $\Delta[\mathrm{CO}]=30$ ppbv. As shown by the minimum PV values depicted in Fig. 2d, the 10-day backward trajectories started along the flight track and coinciding with the drops in $\mathrm{NO}_{\mathrm{y}}$ and $\mathrm{O}_{3}$ partly originated in the troposphere or at least close to the tropopause, where we would expect to find smaller $\mathrm{O}_{3}$ and higher $\mathrm{CO}$ mixing ratios than in the stratosphere. In the upper troposphere $\mathrm{NO}_{\mathrm{y}}$ mixing ratios are also expected to be low provided that the air masses experienced no recent influence of deep convection of polluted planetary boundary air or lightning activity. Values for upper tropospheric air lie between 500 and 1000 pptv as measured during subsequent SPURT winter and autumn campaigns or as reported by Weinheimer et al. (1994). The sharp features of the tracers imply that the mixing between the stratospheric and the tropospheric air masses has not been completed yet, but that

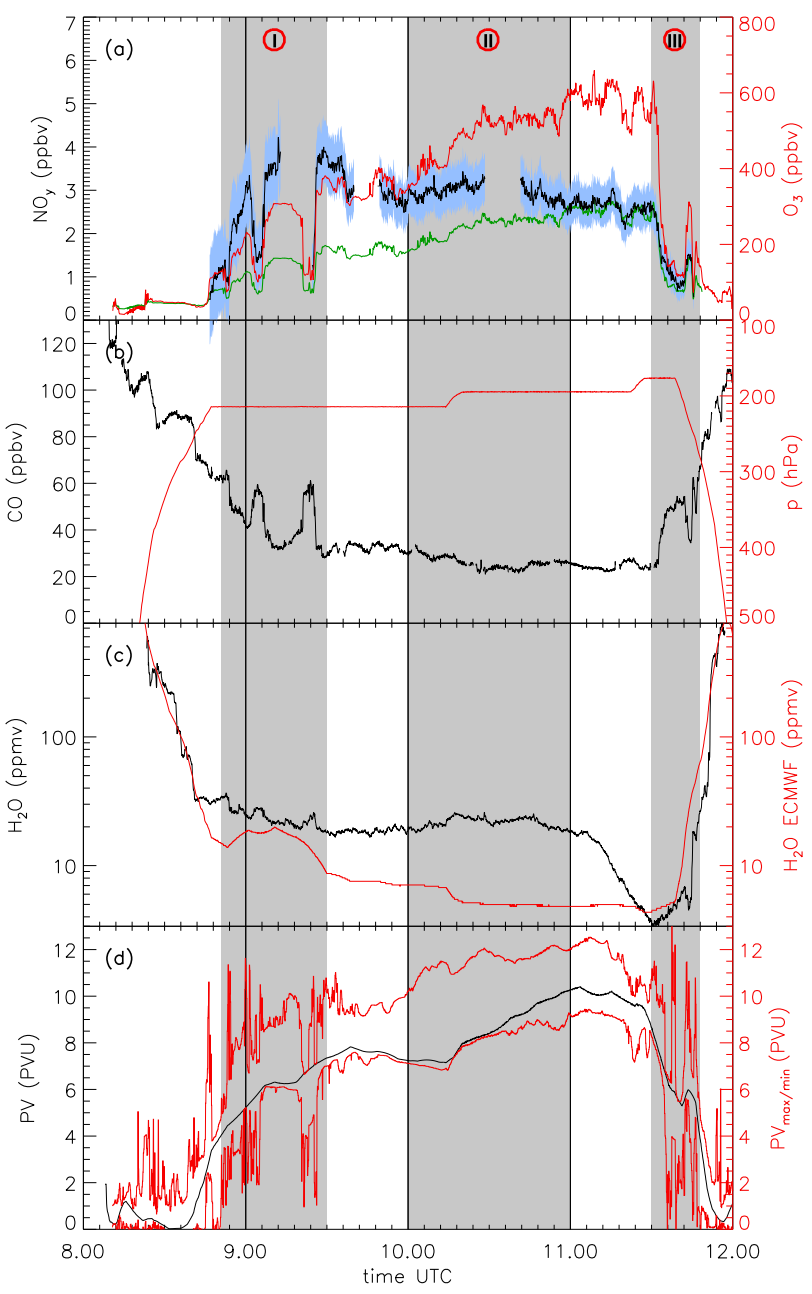

Fig. 2. Time series of trace gases and meteorological parameters during the SPURT mission flight on 10 November 2001. (a) Measured $\mathrm{O}_{3}$ (red), measured $\mathrm{NO}_{\mathrm{y}}$ (black) and its $2 \sigma$ uncertainty (blue shading) and $\mathrm{NO}_{\mathrm{y}}$ as expected from a correlation with $\mathrm{O}_{3}$ (green) (see text). (b) Measured CO (black) and flight pressure altitude (red). (c) Measured total water (black) and water vapor mixing ratio (in ppmv) from ECMWF analyses interpolated in space and time onto flight track (red). (d) PV from ECMWF analyses interpolated onto flight track (black) and minimum and maximum PV along the 10-day backward trajectories started from the flight track (red lines). Grey shading highlights the three different flight segments I, II and III (see Fig. 1 and text for details).

rather the air masses still represent distinct filaments of air with tropospheric and stratospheric characteristics. We used the RDF technique as described above to reproduce the three dimensional structure of the tropospheric filaments similar to Beuermann et al. (2002).

Figure 4 shows that except for the first drop and in contrast to the standard ECMWF analysis (Fig. 4a), rPV fields reproduce the structures in the measurements in almost perfect agreement (Fig. 4b). The horizontal scale of the filaments 

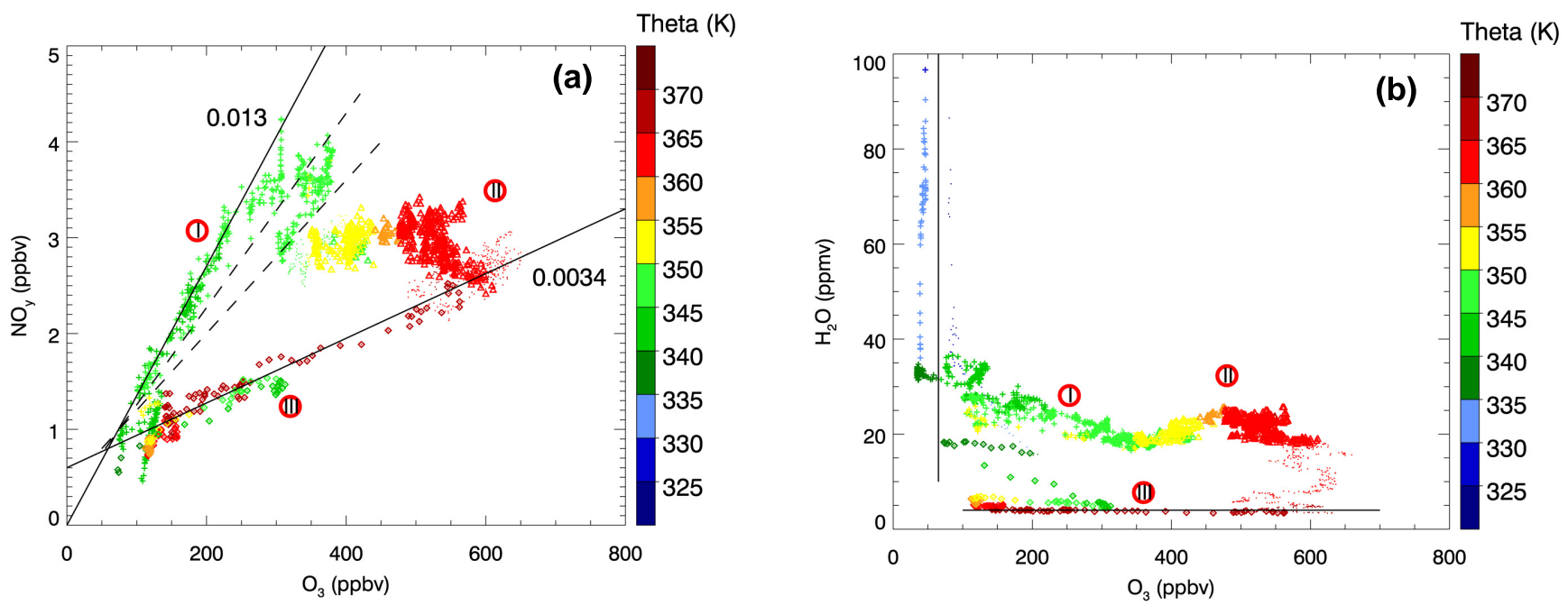

Fig. 3. (a) Tracer correlation between $\mathrm{O}_{3}$ and $\mathrm{NO}_{\mathrm{y}}$ as a function of potential temperature (color coded). In flight segment II (data points depicted as triangles) a strong deviation from the expected linear correlation can be seen. The slope of the correlation, $\mathrm{d}\left[\mathrm{NO}_{\mathrm{y}}\right] / \mathrm{d}\left[\mathrm{O}_{3}\right]=0.0034$, in flight segment III (diamonds) represents a typical value for air from the extratropical stratosphere. Flight segment I (crosses) represents a mixing line between tropospheric air and an atypical stratospheric reservoir, the latter formed formerly by a mixing between a normal stratospheric and an atypical tropospheric reservoir. Dashed lines are hints of additional mixing lines. Data not attributed to a specific flight segment are dotted. (b) Tracer correlation between $\mathrm{O}_{3}$ and $\mathrm{H}_{2} \mathrm{O}$ with analogous labeling. The horizontal black bar denotes the range of expected stratospheric values and the vertical black bar the range of typical tropospheric values. While data of segment I represent a mixing line, data of segment II form a bulge which can not be explained in terms of a simple transition zone between segment I and III.

was between 50 and $100 \mathrm{~km}$ in width and several $1000 \mathrm{~km}$ in length. Their height reached up to a potential temperature level of $370 \mathrm{~K}$, which is normally well within the lowermost stratosphere at mid-latitudes. Evaluation of the backward trajectories shows, that the development of the filaments was initiated on 8 November 2001 by the wrapping of tropospheric air around an almost cut-off stratospheric trough over Newfoundland. This was followed on the next two days by a continuous zonal stretching and meridional compression of both the tropospheric air mass and the trough, now located to the south of the tropospheric air, during their rapid transit across the North Atlantic. Observations of similar yet less pronounced filaments along the western flank of a stratospheric streamer have been reported previously by Bradshaw et al. (2002). They showed that the layering was generated by the breaking of a Rossby wave in the presence of vertical gradients in the background wind fields. The successful reconstruction of the tropospheric filaments coinciding with the drops in the high-spatial resolution tracer measurements shows that the calculated backward trajectories are reliable and that the RDF technique produces an accurate picture of the small scale structures not seen in the PV-fields of the original ECMWF analyses. The filaments represent due to the enlarged contact surface between stratospheric and tropospheric air masses and the strong tracer gradients a high potential for subsequent mixing.

On this flight segment stratospheric $\mathrm{NO}_{\mathrm{y}}$ mixing ratios between and after the tropospheric filaments were much higher than values from the expected $\mathrm{NO}_{\mathrm{y}}-\mathrm{O}_{3}$ correlation given by
Murphy et al. (1993) or Weinheimer et al. (1993) with a slope $\mathrm{dNO}_{\mathrm{y}} / \mathrm{dO}_{3} \sim 0.004$. The correlation between $\mathrm{NO}_{\mathrm{y}}$ and $\mathrm{O}_{3}$ is well established and supposed to show only little variation in the LMS besides a certain latitudinal dependence (Ziereis et al., 2000). The scatter plot of $\mathrm{NO}_{y}$ versus $\mathrm{O}_{3}$ (Fig. 3a) from the here presented measurements clearly shows the different relations between the two species in the different phases of the flight. The expected slope close to 0.004 was only observed later on the flight in segment III (see Sect. 5.2). In contrast to the here presented data, the $\mathrm{NO}_{\mathrm{y}} / \mathrm{O}_{3}$ correlations obtained during two subsequent flights on the following day were well within the range of correlations found in former observations. In order to illustrate how unusual the observed $\mathrm{NO}_{\mathrm{y}}$ mixing ratios were during most of the time the $\mathrm{NO}_{\mathrm{y}}$ values calculated from the ozone data using the above correlation are indicated by the green line in Fig. 2a. Higher slopes of $\mathrm{NO}_{\mathrm{y}} / \mathrm{O}_{3}$ correlations up to 0.01 were found by Bregman et al. (1995) during STREAM I and Fischer et al. (1997) during STREAM II and were attributed to renitrification which is unlikely to take place in November. Ray et al. (1999) however concluded from balloon measurements of different CFCs that the lowermost stratosphere in summer and autumn may be stronger influenced by isentropic transport from the tropical upper troposphere than in other seasons. Hoor et al. (2004) present in a more detailed study with broader latitudinal and seasonal coverage than the measurements of Ray et al. (1999) that isentropic transport indeed affects a distinct layer of $\Delta \Theta=30 \mathrm{~K}$ above the tropopause in summer with decreasing tropospheric influence beyond this layer. Higher 


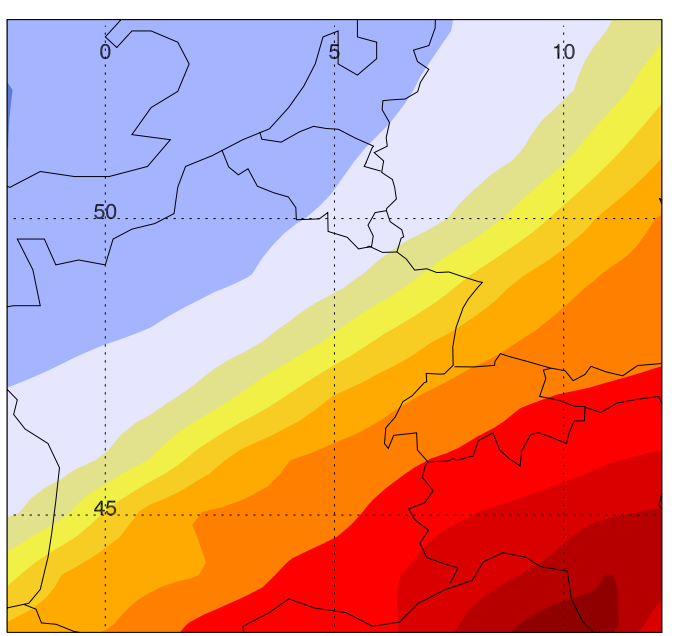

(a)

(b)

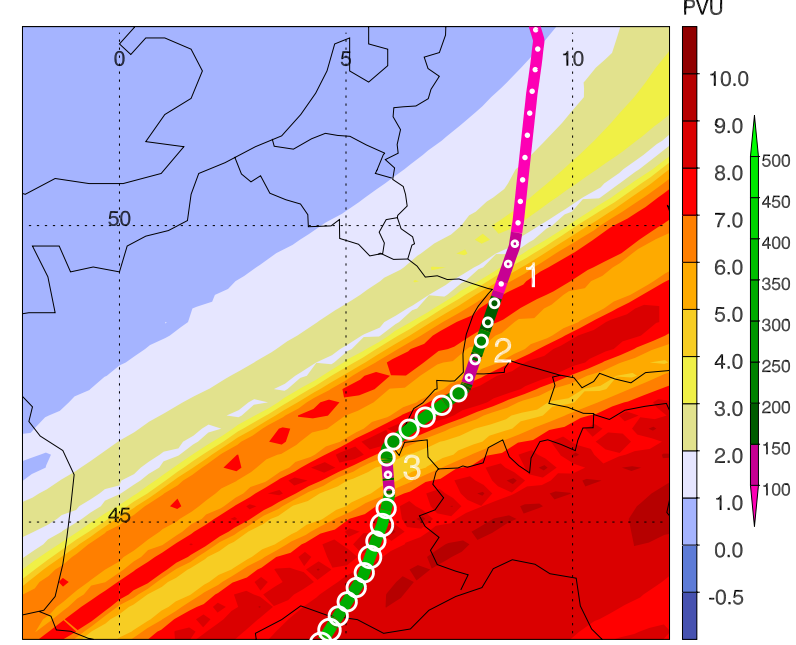

Fig. 4. PV from standard ECMWF analysis (a) and RDF-reconstructed rPV with an integration time of $24 \mathrm{~h}$ (b) at $210 \mathrm{hPa}$ on $10 \mathrm{November}$ 2001 09:00 UTC (in PV-units, PVU, color-coded). See Sect. 3.2 for details about the reconstruction technique. The $\mathrm{O}_{3}$ mixing ratio along the flight is overlaid as a thick colored line with colors ranging from purple to green. The $\mathrm{O}_{3}$ mixing ratio is also represented by the white circles, the radius being proportional to the mixing ratio. Drops in mixing ratio coincide with filaments of lower rPV-values almost perfectly.

$\mathrm{NO}_{\mathrm{y}}$ mixing ratios as obtained in the probed subtropical air masses during flight segment I therefore could result by isentropic mixing. Nevertheless, the mean $\mathrm{NO}_{\mathrm{y}}$ mixing ratios in the upper troposphere between 0.75 and 3 ppbv during summer and autumn (Fischer et al., 2000) may only partly attribute to the observed elevated $\mathrm{NO}_{\mathrm{y}}$ mixing ratios. Also, the measurements were taken in a $\Delta \Theta$ range between $35 \mathrm{~K}$ and $55 \mathrm{~K}$ above the tropopause and therefore we assume that the here presented measurements indicate a rather exceptional feature. It is important to note that the contamination problem mentioned in Sect. 2 can not be responsible for the unusually steep slope seen in flight segment I. The individual points on this line belong to the rapid transitions from stratospheric air into tropospheric air and back when the aircraft passed the flanks of the tropospheric filaments. These transitions occurred on a time scale of only 1-2 min which is much too short for significant changes in the background signal. A contamination effect still unaccounted for in the data would simply shift the correlation line up or down on the y-axis but would not affect its slope. The steep slope as well as the high absolute $\mathrm{NO}_{\mathrm{y}}$ mixing ratios at the upper end of the correlation line indicates that stratospheric air with unusually high $\mathrm{NO}_{\mathrm{y}}$ mixing ratios has mixed with tropospheric air. $\mathrm{H}_{2} \mathrm{O}$ mixing ratios (Fig. 2c) were also higher than stratospheric mixing ratios of a few ppmv. However, these enhanced values are frequently observed in a mixing layer close to the troposphere at $\mathrm{O}_{3}$ mixing ratios of 200-300 ppbv (Schiller et al., in preparation, $2004^{3}$ ) and are further reproduced by the

\footnotetext{
${ }^{3}$ Schiller, C.: Seasonal and longitudinal variability of water vapor and inferred transport processes in the lowermost stratosphere, in preparation, 2004.
}

ECMWF model. The high $\mathrm{NO}_{\mathrm{y}}$ mixing ratios in the stratospheric air are most probably of tropospheric origin. Figure 5 shows that the majority of air parcels in the vicinity of the flight track in segment I has experienced troposphereto-stratosphere transport between 6 and 10 days prior to the measurements (light to dark blue boxes). The tropospheric filaments described above, on the other hand, are significantly younger than this and are represented by the yellow to red boxes. The trajectory analysis thus suggests that the unusual tracer relation results from two subsequent mixing processes, the first one taking place between 1 and 4 November (or even before) and transporting tropospheric air with high $\mathrm{NO}_{\mathrm{y}}$ mixing ratios of about 4 to $5 \mathrm{ppbv}$ into the stratosphere, and the second one taking place between 5 and 9 November transporting again tropospheric air into the stratosphere but this time with low $\mathrm{NO}_{\mathrm{y}}$ mixing ratios of less than $1 \mathrm{ppbv}$. It yet remains unclear what caused the high $\mathrm{NO}_{\mathrm{y}}$ mixing ratios in this first mixing process. Possible explanations remain that the tropospheric air masses introduced into the LMS during the first mixing process were impacted by $\mathrm{NO}_{\mathrm{x}}$ production by lightning or transport from polluted planetary boundary layer air to the upper troposphere through deep convection.

\subsection{Flight-segment III}

On the third flight-level, at the exit of the streamer, we observed a strong gradient in the measured trace gases though the aircraft remained at a constant pressure of $176 \mathrm{hPa}$ and an almost constant potential temperature of about $365 \mathrm{~K} . \mathrm{NO}_{\mathrm{y}}$ decreased within $10 \mathrm{~min}$ from 2.6 to $0.8 \mathrm{ppbv}$ and at the same time $\mathrm{O}_{3}$ decreased from about 600 to $100 \mathrm{ppbv}$. The correlation between the two tracers with a slope of 0.0034 is 


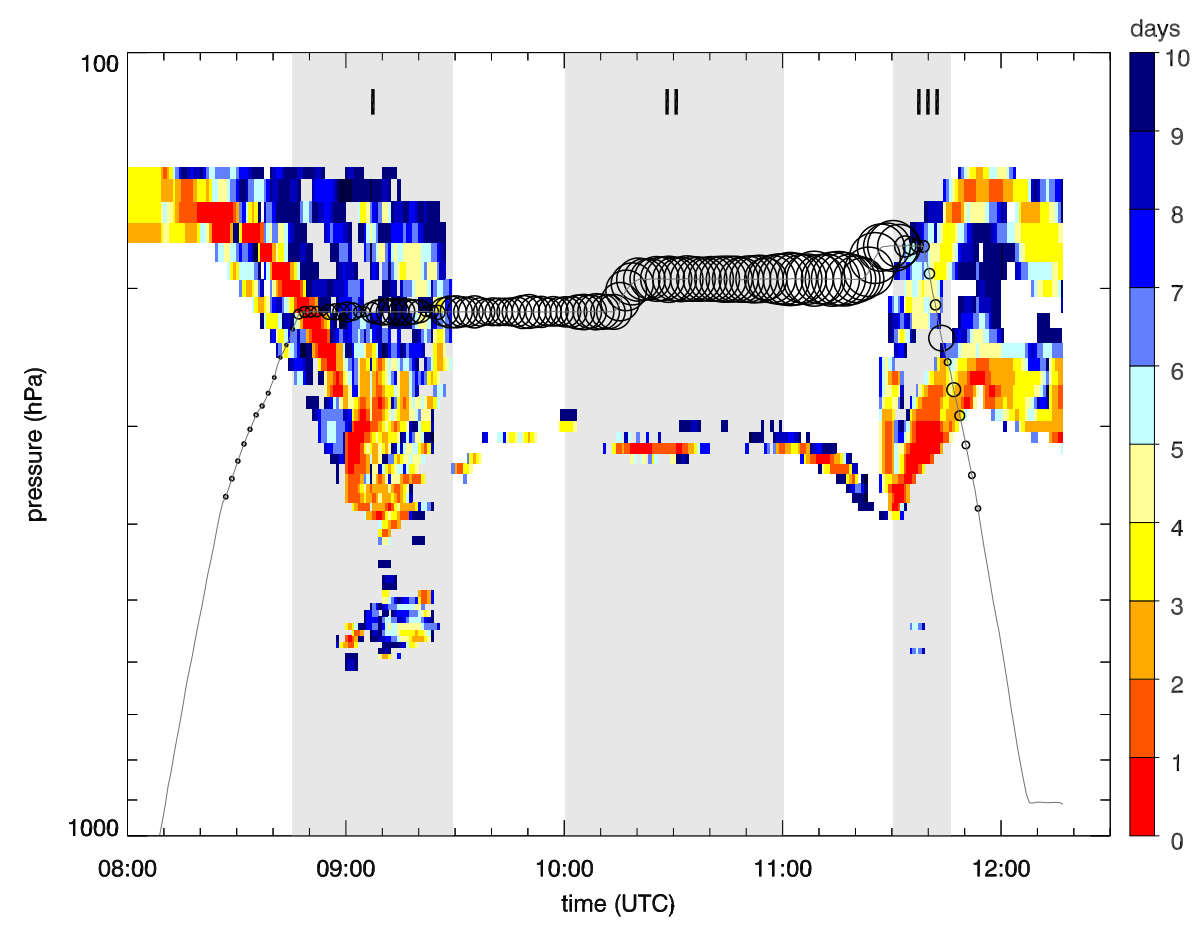

Fig. 5. Flight-track-following vertical cross section of the day an air parcel experienced TST. Air parcel trajectories were calculated 10 days backward from a fine 3-D grid and starting at three different times (06:00, 09:00 and 12:00 UTC) on 10 November as described in Sect. 3.2. The day when TST occurred was then projected onto the start points of the trajectories (i.e. onto the 3-D grid) and finally these values were interpolated in time and space onto vertical columns along the flight track. Only air parcels having a PV value greater than 3 PVU at the time of the flight may have experienced TST. The day of TST is defined as the last day the air parcels' PV value was below 3 PVU. A value of 8 , for example, indicates that TST occurred 8 days before the flight. The majority of air parcels has not experienced TST and is therefore left white. The lower border of the colored regions follows approximately the tropopause. Black circles represent the $\mathrm{O}_{3}$ measurements, the radius being proportional to the mixing ratios.

typical for air from the extratropical stratosphere between 10 and $18 \mathrm{~km}$ (Murphy et al., 1993; Weinheimer et al., 1993). The trace gas features in this segment can be well understood by looking at a vertical west-east cross-section of the intrusion as shown in Fig. 6. As the aircraft passed through the western flank of the streamer, it encountered a strong gradient in PV (blue circle in Fig. 6). The figure even provides an explanation for the $\mathrm{O}_{3}$ peak observed just after the described gradient during descent at about $250 \mathrm{hPa}$ where the aircraft approached a bulge in the streamer (blue arrow in Fig. 6). The concurrent increase in PV can also be seen in Fig. 2d at about 11:45 UTC. This again demonstrates how well the structure and positioning of the western flank of the streamer is represented in the ECMWF analyses. The RDF analysis shows that the air inside the streamer has originated from high polar latitudes whereas to the west of the streamer subtropical air has been advected northwards along the ridge over the Atlantic. This has not only brought together two air masses of very different dynamical properties (high and low PV) but also of different chemical characteristics. The steep quasi-isentropic gradients in the tracers generated in this way insinuates a high potential for cross-tropopause exchange, in- duced for instance by clear-air turbulence in the vicinity of the jet stream (Pepler et al., 1998).

\subsection{Flight-segment II: standard analysis}

While $\mathrm{O}_{3}$ and $\mathrm{NO}_{\mathrm{y}}$ in the undisturbed stratosphere are expected to correlate positively with a slope between 0.003 and 0.006 (Murphy et al., 1993; Weinheimer et al., 1993), we observed a weak negative correlation in segment II (see Fig. 3a), suggesting that these air masses have been severely perturbed by air containing higher mixing ratios of $\mathrm{NO}_{\mathrm{y}}$ than expected. This is corroborated by the measurements of $\mathrm{H}_{2} \mathrm{O}$ which show remarkable differences from the mixing ratios normally found in the stratosphere. In contrast to flight segment $\mathrm{I}, \mathrm{H}_{2} \mathrm{O}$ mixing ratios modeled by ECMWF are only between 5 and 8 ppmv as opposed to measured values between 20 and 30 ppmv (see Fig. 2c), which are among the highest $\mathrm{H}_{2} \mathrm{O}$ mixing ratios ever observed in air masses with $\mathrm{O}_{3}>500$ ppbv (Schiller et al., in preparation, 2004 ${ }^{4}$ ). This

\footnotetext{
${ }^{4}$ Schiller, C.: Seasonal and longitudinal variability of water vapor and inferred transport processes in the lowermost stratosphere, in preparation, 2004.
} 


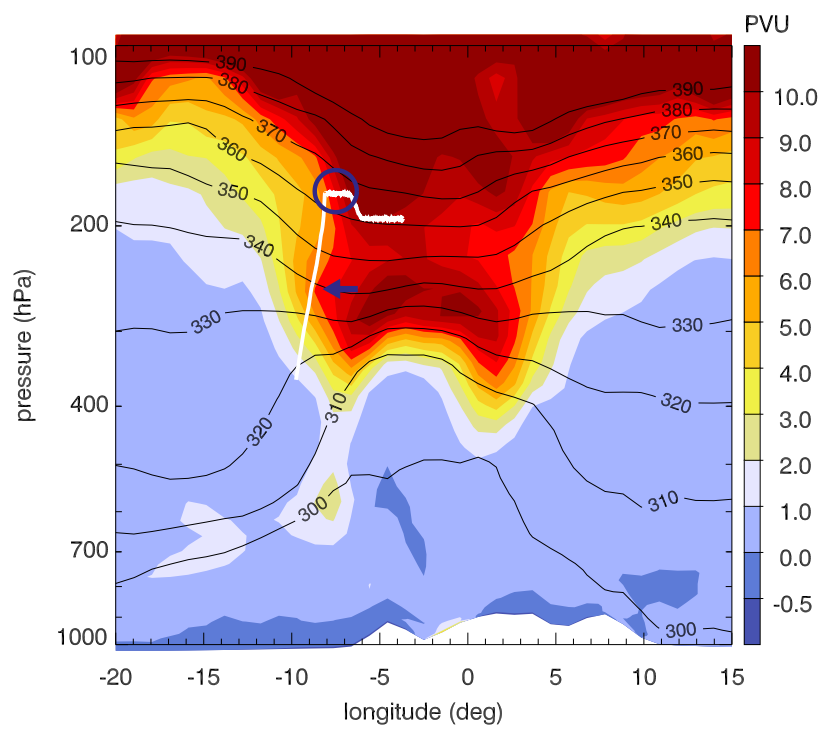

Fig. 6. Flight path (white) corresponding to segment III and potential temperature (black lines) overlaid on a vertical cross section of PV (color-coded) at $35^{\circ} \mathrm{N}$ on 10 November 2001 12:00 UTC. The strong PV-gradient indicated by the blue circle is associated with a linear correlation between $\mathrm{NO}_{y}$ and $\mathrm{O}_{3}$ mixing ratios as described in Sect. 5.2. The blue arrow points to a bulge in the streamer coinciding with a secondary peak in the $\mathrm{NO}_{\mathrm{y}}$ and $\mathrm{O}_{3}$ mixing ratios.

results in a bulge in the $\mathrm{O}_{3} / \mathrm{H}_{2} \mathrm{O}$ relationship as shown in Fig. $3 \mathrm{~b}$ which can not be simply explained by a mixing between air masses of segment I and III.

Figure 7 shows the different origin of the air parcel trajectories started from flight segment I (Fig. 7a) and II (Fig. 7b). The trajectories in segment II are clearly stratospheric with maximum PV values of $12 \mathrm{PVU}$ and a minimum value of about 8 PVU (see Fig. 2d). They remained together during the previous 10 days following a path circulating about the north pole. In contrast, the trajectories of segment I originated in the subtropics and mid-latitudes with much lower PV maxima and minima. Also different from segment I, trajectories started from the RDF grid in the vicinity of the flight track show a clear stratospheric signature with no indication of TST during the previous 10 days (see Fig. 5). These findings suggest that in contrast to segment I the introduction of tropospheric air most likely did not happen through a process resolved by the ECMWF wind fields, at least not during the time period covered by the trajectories. However, the potential for transport and mixing at an earlier time, e.g. several months before sampling, is currently being studied with the 3 -D version of the Chemical Lagrangian Model of the Stratosphere (CLaMS) (Günther et al., in preparation, 2004 ${ }^{5}$ ).

Denitrification and subsequent renitrification as a possible source for enhanced $\mathrm{NO}_{\mathrm{y}}$ mixing ratios (Koike et al., 2002)

\footnotetext{
${ }^{5}$ Günther, G.: Impact of TST and cirrus clouds on the water vapour budget of the LMS, in preparation, 2004.
}
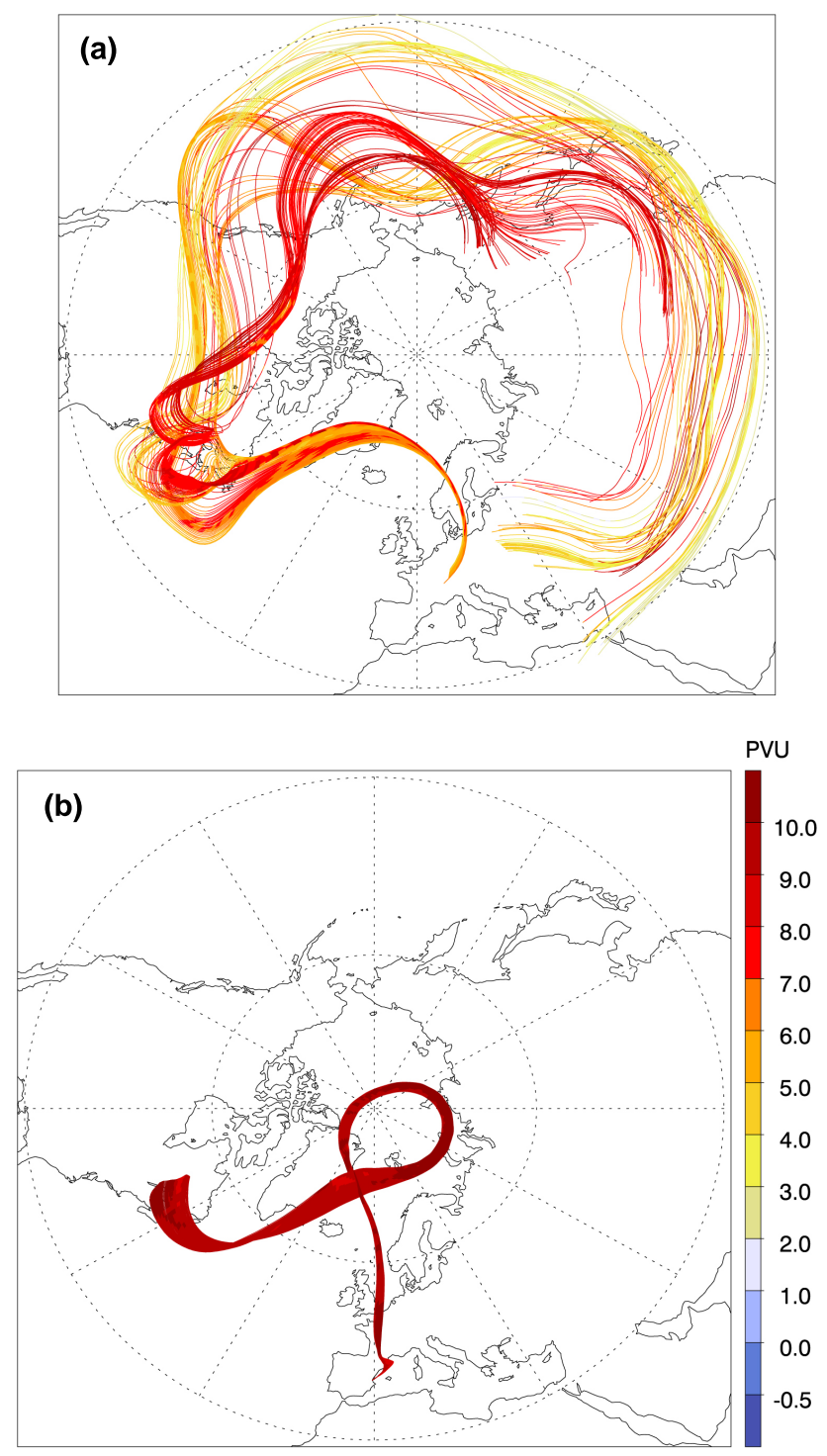

Fig. 7. 10-day backward trajectories along the flight path arriving between 09:00 UTC and 09:24 UTC at the flight path in flight segment I (a) and between 10:24 and 10:48 UTC in flight segment II (b). The color code indicates the PV of the air.

is not expected at this time of the year. Another possible explanation for both elevated $\mathrm{NO}_{\mathrm{y}}$ and $\mathrm{H}_{2} \mathrm{O}$ mixing ratios is injection of tropospheric air through deep convection. The outflow of deep convective clouds may be strongly enhanced in $\mathrm{NO}_{\mathrm{x}}$ due to lightning (Brunner et al., 1998; Huntrieser et al., 1998; Lange et al., 2001). In Fig. 8 a Meteosat water vapor image is overlaid with the flight path (along orange circles) and with the $2 \mathrm{PVU}$ contours at 200 and $350 \mathrm{hPa}$ (dashed and solid blue line) marking the position of the streamer at two different altitudes. Widespread convection (bright areas) covers the Mediterranean with centers of activity located near the east coast of the Iberian peninsula and near Corsica, Sardinia and middle Italy. The area of convective activity is quite 


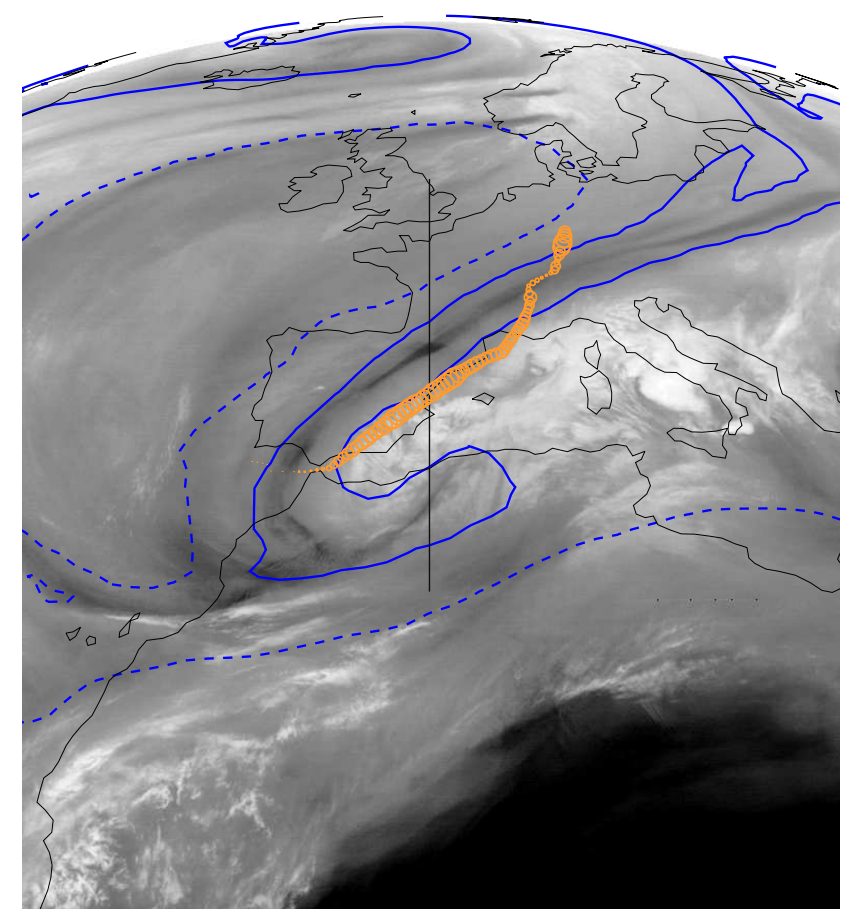

Fig. 8. Difference between measured and modeled (directly offered by ECMWF) $\mathrm{H}_{2} \mathrm{O}$ (size of the orange circles) overlaid on the water vapor satellite image of 10 November 2001 09:00 UTC. Blue dashed line: $2 \mathrm{PV}$ contour on $200 \mathrm{hPa}$ level. Blue solid line: $2 \mathrm{PV}$ contour on $350 \mathrm{hPa}$ level. Bright (wet) areas in the image indicate regions with high reaching convective clouds. Note the strong spatial correlation between the dark (dry) elongated area and the position of the streamer represented by the $2 \mathrm{PV}$ contour at $350 \mathrm{hPa}$. Black solid line: location of the vertical cross sections in Fig. 9.

sharply delimited by the stratospheric streamer which is seen as an elongated dark band of dry air, and which is very well represented by the $2 \mathrm{PVU}$ contour at $350 \mathrm{hPa}$ in the ECMWF model. The PV streamer has been responsible for the destabilizing of air and for triggering the convection on its forward flank. The radius of the orange circles along the flight path is proportional to the difference in $\mathrm{H}_{2} \mathrm{O}$ volume mixing ratios between measurements and ECMWF analysis, and is thus a measure for the enhancement in $\mathrm{H}_{2} \mathrm{O}$. The figure shows that the region of enhanced water vapor mixing ratios corresponds to the part of the flight carried out southward of the center of the streamer and hence close to the areas of convective activity. However, according to the ECMWF analysis the aircraft was flying well above the tropopause. The ECMWF tropopause (taken as the $2 \mathrm{PVU}$ surface) was located at about $340 \mathrm{hPa}$ in flight segment II whereas the aircraft was flying at about $200 \mathrm{hPa}$ as shown in a vertical north-south cross section in Fig. 9a. The cross section follows the black line in Fig. 8. Because the ECMWF model is not able to resolve the probably important small-scale features associated with the convective systems, we also analyzed the situation as simu- lated by the Climate High Resolution Model (CHRM). The cloud layers generated in the CHRM are highly consistent with the observed clouds over the Mediterranean. The corresponding convective activity has generated a lot of fine scale structure around the tropopause and has pushed the $2 \mathrm{PVU}$ surface to about $270 \mathrm{hPa}$ at $37^{\circ} \mathrm{N}$ (see Fig. 9b). This is significantly higher than in the ECMWF model but still well below flight altitude. Similar to the ECMWF model the CHRM shows no enhanced water vapor at flight level suggesting no connection between the observed elevated $\mathrm{H}_{2} \mathrm{O}$ mixing ratios and the nearby convective activity. However, Fig. 8 only provides a picture of the convective activity for a single time, while numerous convective cells developed already during the previous day. The predictive capability of the CHRM for the location and particular timing of such an observed small-scale tracer anomaly is limited. This might be due to the particular model formulation for subgrid-scale or nonhydrostatic processes - and in fact, it is conceivable, that an element of both is present. For instance, processes associated with deep convection could be poorly represented by the parameterization, and subgrid-scale, non-hydrostatic or smallscale turbulent effects are inaccessible for investigation with the present model's approximations.

\subsection{Flight-segment II: convective influence analysis}

As shown in the previous section, the analyses based on fields simulated by the ECMWF and CHRM are unable to explain the unusually high $\mathrm{NO}_{\mathrm{y}}$ and $\mathrm{H}_{2} \mathrm{O}$ mixing ratios in flight segment II. In order to obtain an integral picture of the convective influence experienced by each air parcel of the RDF grid, we traced the convective activity observed by the Meteosat infrared channel along the backward trajectories over the course of the previous 1.5 days (from 9 November 00:00 UTC to 10 November 12:00 UTC). At each time step (30 $\mathrm{min})$ the air parcels temperature was compared to the brightness temperature of the coinciding satellite pixel, and whenever the temperature was higher, the air parcel was said to have undergone convective influence, similar to the approach used by Jeker et al. (2000). Individual convective influences along a trajectory were then summed up, converted into an overall "convective influence time", and projected forward onto the trajectory start points. Figure 10 shows the results of this analysis for backward trajectories started on the $200 \mathrm{hPa}$ level (and therefore on flight level). In segment II the aircraft was closely following the northwestern edge of a region which experienced significant convective influence. Individual air parcels in this area remained up to 8 out of $36 \mathrm{~h}$ inside or below high (cold) clouds. Closer inspection of the paths of these air parcels reveals that they have crossed areas of intense lightning activity over northern and southern Spain and over the north coast of Algeria (see Fig. 11). The encounter time corresponds to the time of the most vigorous lightning activity on the evening of 9 November (dark blue to bright blue spots in Fig. 11). 


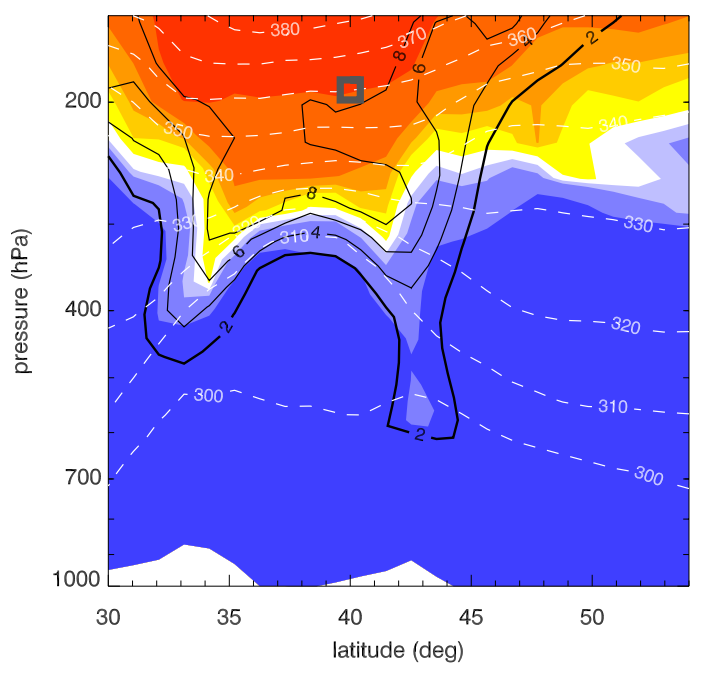

(a)

Fig. 9. Vertical cross sections of $\mathrm{H}_{2} \mathrm{O}$ mixing ratio (in ppmv, color coded) from $30^{\circ} \mathrm{N}$ to $54^{\circ} \mathrm{N}$ latitude at $0^{\circ}$ longitude from ECMWF (a) and from a CHRM simulation (b) on 10 November 2001 09:00 UTC. Black curves: PV. White dashed lines: potential temperature. Grey square: flight position. While the tropopause in ECMWF model lies at about $340 \mathrm{hPa}$, the tropopause reaches in the CHRM up to about $270 \mathrm{hPa}$.

A comparison between ECMWF winds interpolated onto the flight track and the wind measured aboard the aircraft reveals notable differences for the time between 10:00 and 11:00 UTC (see Fig. 12). The ECMWF analysis shows northeasterly winds (between $55-65^{\circ}$ ) whereas the measurements show a much stronger easterly component $\left(70-90^{\circ}\right)$. The significant differences between measured and ECMWF analyzed wind directions, which was seen only in segment II, is probably due to the fact that the aircraft was flying close to a shear line marking the center of the streamer at $200 \mathrm{hPa}$. Across this shear line the wind changed dramatically from northern to southern directions and therefore small errors in the positioning of this line would result in large errors in the predicted wind direction. It appears that part of the outflow of the convective activity over the Mediterranean was directed more strongly towards the west than simulated by the ECMWF model, resulting in a more eastern wind component on the flight track than predicted by the model.

The above analyses suggest that convective injection of tropospheric air, enhanced in NO through lightning activity, may indeed serve as an explanation for the elevated $\mathrm{H}_{2} \mathrm{O}$ and $\mathrm{NO}_{\mathrm{y}}$ mixing ratios. Most of the troposphere-tostratosphere transport appears to have occurred more than $12 \mathrm{~h}$ earlier in convective systems over northern and southern Spain and over Algeria. Turbulent mixing close in the outflow to the deep convective cells may have smeared out individual plumes in the following hours resulting in a rather uniform enhancement in the tracers as observed from the aircraft.

In order to estimate the amount of $\mathrm{NO}_{\mathrm{y}}$ and $\mathrm{H}_{2} \mathrm{O}$ initially contained in the injected tropospheric air, we performed a

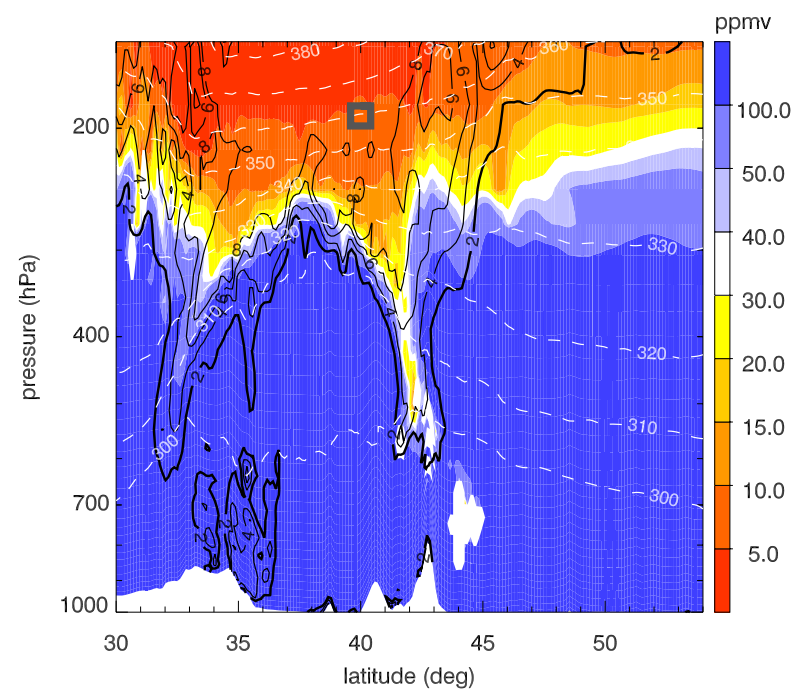

(b)

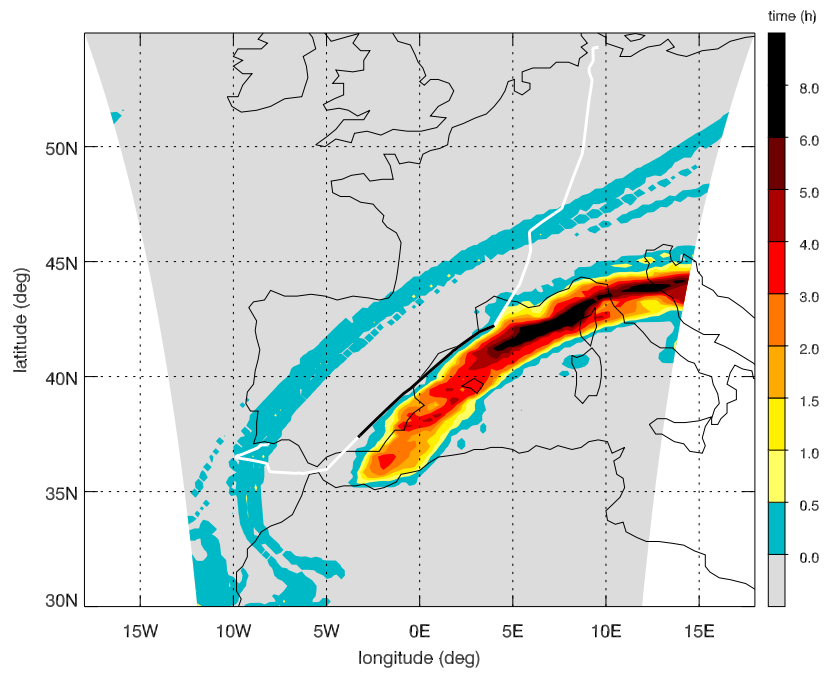

Fig. 10. Convective influence plot of the grid points on the $200 \mathrm{hPa}$ level at 12 UTC. The color code indicates the total time (in hours) integrated over the previous 1.5 days during which the air parcels experienced higher temperatures than the brightness temperatures (BT) of the collocated satellite pixels. Only satellite pixels with BT of less than $-50^{\circ} \mathrm{C}$ were considered in order to take only high (anvil) clouds into account. The flight path is overlaid in white. Flight segment II is shown in black.

simple mass balance calculation following Ray et al. (1999). The measured CO mixing ratios along segment II (ranging from 25 to $35 \mathrm{ppbv}$ ) were used to quantify the fraction of tropospheric air within the probed air masses, based 


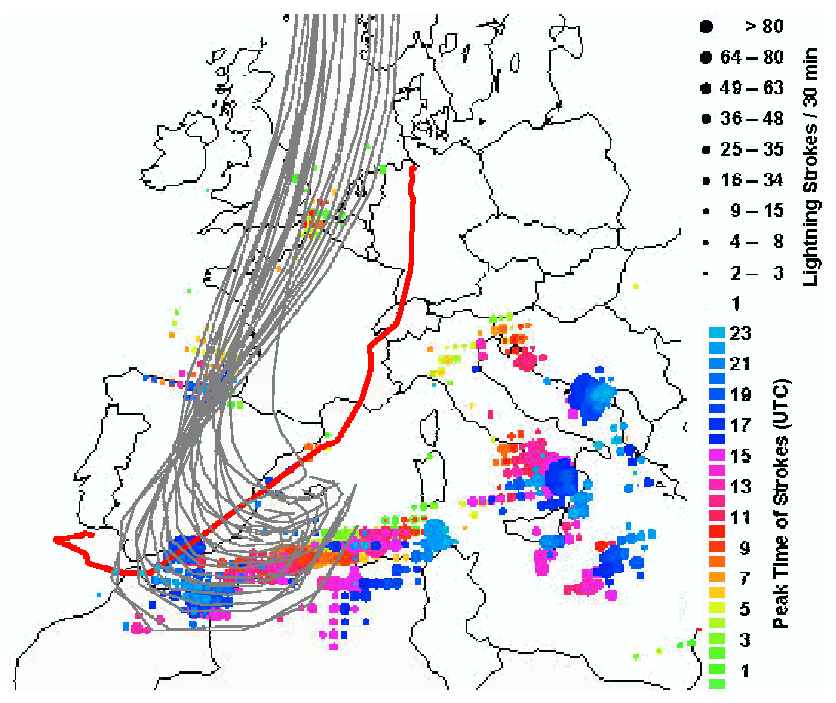

Fig. 11. Flight path (red line) and backward trajectories started from $200 \mathrm{hPa}$ in the convective influence region identified in Fig. 10 on 10 November 12:00 UTC (grey lines) overlaid on a "Sferics" image of the 9 November 2001 freely adapted from http://www. wetterzentrale.de/. The "Sferics" image represents all registered lightning strokes sampled by the Arrival Time Difference (ATD) system of the UK Meteorological Office. Radio waves emitted by lightning strokes are picked up by radio sensors at different stations in Europe and the location of the lightning is determined from the difference in the arrival time at each station. The size of the circles represents the amount of registered lightning per $30 \mathrm{~min}$ at one location and the color coding indicates the time of the day at which the discharges occurred. The figure shows that the trajectories south east of the flight path crossed areas of high lightning activity over northern and southern Spain and the north coast of Algeria.

on estimates of $\mathrm{CO}$ mixing ratios in the undisturbed stratosphere (15-20 ppbv)(Hoor et al., 2002) and in the troposphere $(70 \mathrm{ppbv}$ as measured during a second flight on the same day in tropospheric and subtropical air masses or as taken from a classification by Fischer et al., 2002). From this we inferred that between 5 and $20 \%$ tropospheric air has been mixed into the lowermost stratosphere and that this tropospheric air originally contained between 6 and $10 \mathrm{ppbv}$ $\mathrm{NO}_{y}$ and between 100 and 400 ppmv $\mathrm{H}_{2} \mathrm{O}$. The mixing ratios for $\mathrm{NO}_{\mathrm{y}}$ in the tropospheric air calculated in this way are rather high, but previous studies already reported on mixing ratios around 3 ppbv $\mathrm{NO}_{\mathrm{y}}$ (Lange et al., 2001) or even up to 5 ppbv $\mathrm{NO}_{\mathrm{x}}$ (Brunner et al., 1998) measured in regions of convective outflow. The air masses probably influenced by the lightning and convective activity over northern and southern Spain and Algeria end up in that part of the colored area in Fig. 10 which lies to the west of $5^{\circ} \mathrm{E}$. This area has a size of approximately $3.5 \times 10^{5} \mathrm{~km}^{2}$ and if we assume that the convective outflow occurred in a layer of about $3 \mathrm{~km}$ thickness we can calculate a total volume of the outflow air of $1.05 \times 10^{6} \mathrm{~km}^{3}$. The total number of lightning strokes registered by the Arrival Time Detection Sys-

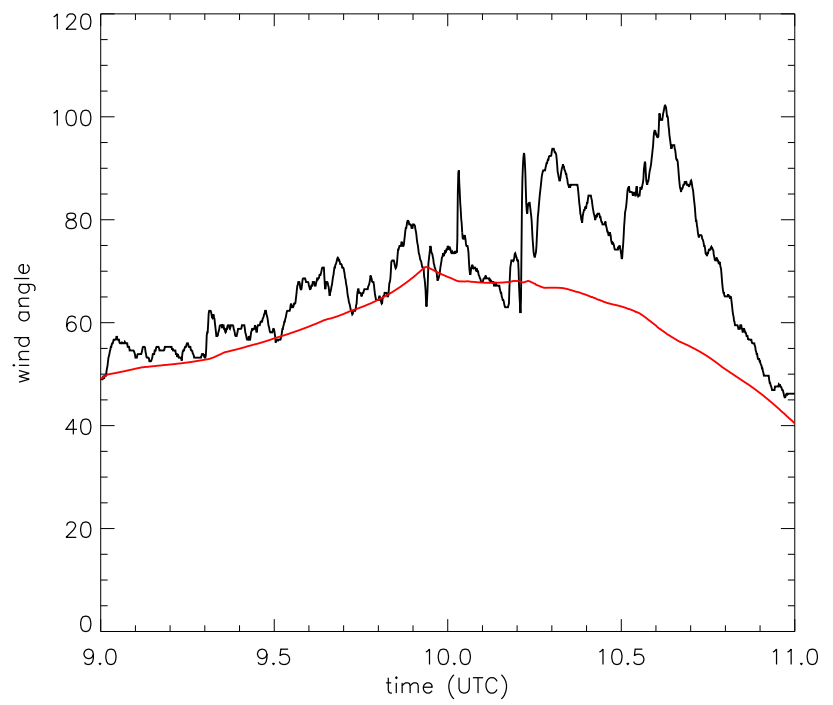

Fig. 12. By ECMWF analyzed wind along the flight path (red) and the wind measured by the aircraft instrumentation (black). The aircraft experienced wind with a more easterly component than given by the model, indicating that the flight path lied closer to the outflow region of the convective system over the western Mediterranean.

tem of the UK Meteorological Office between 9 November 00:00 UTC and 10 November 12:00 UTC in the convective systems over the considered region sums up to about 11200. Assuming a NO production of $4 \times 10^{26}$ molecules per flash (Drapcho et al., 1983) and assuming that up to $75 \%$ of the produced $\mathrm{NO}_{\mathrm{x}}$ ends up in the upper troposphere above $8 \mathrm{~km}$ (Pickering et al., 1998) we can estimate an average $\mathrm{NO}_{\mathrm{y}} \mathrm{mix}$ ing ratio of $0.7 \mathrm{ppbv}$ due to lightning activity alone. Part of this $\mathrm{NO}_{\mathrm{y}}$-rich air is eventually mixed into the LMS and increased the $\mathrm{NO}_{\mathrm{y}}$ mixing ratios along the flight path. However, the $0.7 \mathrm{ppbv}$ are roughly one order of magnitude less than the 6 to $10 \mathrm{ppbv}$ required to explain the observations and we can only speculate on possible reasons for this. Either the assumption of $4 \times 10^{26}$ molecules per lightning flash is much too low, or the assumptions on the total volume of convective outflow is overestimated, or other sources unaccounted for in our estimates such as aircraft emissions must have contributed substantially. Note that correlations with $\mathrm{CO}$ and $\mathrm{CO}_{2}$ do not indicate a significant influence on $\mathrm{NO}_{\mathrm{y}}$ through transport of polluted planetary boundary air. However, elevated tropospheric $\mathrm{NO}_{2}$ columns in the area of the flight track on 10 November have also been observed from space by the GOME instrument and were attributed to the lightning activity over the Mediterranean (Thomas et al., 2003). Thomas et al. (2003) calculated a maximum tropospheric column content of $5.5 \times 10^{15}$ molecules $\mathrm{cm}^{-2}$ on 11 November and attributed the enhancement to a layer located above cloud levels. Assuming a column-height between clouds and tropopause of $3 \mathrm{~km}$ a $\mathrm{NO}_{2}$ mixing ratio of $1.5 \mathrm{ppbv}$ results. With a typical ratio $\mathrm{NO} / \mathrm{NO}_{2}$ in photochemical equilibrium 
of $4: 1$ the expected NO mixing ratio would be around $6 \mathrm{ppbv}$ and would thus be able to explain our findings.

Finally, we calculated 10-day forward trajectories to estimate the stratospheric residence time of this strongly affected air mass in order to judge whether the perturbation to the LMS was long-lasting and hence significant following the arguments for detecting significant TST events presented by Wernli and Bourqui (2002). The results show, that $97 \%$ of the air parcels, which started on the $200 \mathrm{hPa}$-level and experienced strong convective influence as seen in Fig. 10, remain in the lowermost stratosphere and therefore may have a considerable impact on the chemical and radiative properties of this region.

\section{Conclusions}

We have reported on airborne measurements of $\mathrm{NO}_{\mathrm{y}}$ and other tracers in the lowermost stratosphere during an extraordinary meteorological episode featuring a deep stratospheric intrusion over south-western Europe.

At the south-western edge of the streamer, a strong gradient in the $\mathrm{NO}_{\mathrm{y}}$ and the $\mathrm{O}_{3}$ mixing ratios has been encountered while flying on a constant pressure $(176 \mathrm{hPa})$ and on an almost constant potential temperature level $(365 \mathrm{~K})$. In agreement with the tracer observations the ECMWF analysis shows a strong gradient in PV along this flight segment demonstrating how well the model located the position of this part of the streamer.

Sudden drops in $\mathrm{NO}_{\mathrm{y}}$ and $\mathrm{O}_{3}$ at the western flank of the streamer could be well understood by reconstruction of the fine scale structures in potential vorticity using the RDF technique, which showed the presence of a sequence of three narrow tropospheric filaments embedded into the stratospheric streamer. The steep tracer gradients at the borders of these filaments indicate that only little mixing with the surrounding stratospheric air had occurred at that stage. Mixing is most likely taking place later on as the tropospheric air masses are stretched into ever longer and narrower filaments. The air with stratospheric characteristics located between the filaments showed strongly enhanced $\mathrm{NO}_{\mathrm{y}}$ mixing ratios, which probably was introduced by TST about 10 days ago, long before the formation of the tropospheric filaments occurred. However, given the uncertainty in trajectory calculations over 10 days backward we were not able to find a fully conclusive explanation for these elevated $\mathrm{NO}_{\mathrm{y}}$ mixing ratios.

During the second flight segment in the interior of the streamer, however, strongly enhanced mixing ratios of $\mathrm{NO}_{\mathrm{y}}$ by up to $100 \%$ of the expected values are shown to be most probably caused by recent mixing with tropospheric air through injection by deep convection on the forward (eastern) flank of the streamer. The data are corroborated by observations of $\mathrm{H}_{2} \mathrm{O}$ showing enhancements of up to $200 \%$. Neither the ECMWF model nor the mesoscale CHRM are able to reproduce the observed enhancement in $\mathrm{H}_{2} \mathrm{O}$ in the lowermost stratosphere at the altitude of the aircraft. Convective activity in the two models extends only to about $340 \mathrm{hPa}$ and $270 \mathrm{hPa}$, respectively, well below flight altitude of about $200 \mathrm{hPa}$. The impact of the convective system with its continuously developing cells during the previous two days was potentially large and the outflow region stretched along the flight path over a distance of about $700 \mathrm{~km}$.

We traced convective influence along backward trajectories started from a large area surrounding the flight track at $200 \mathrm{hPa}$ using the observations of cold (high) clouds observed by Meteosat at $30 \mathrm{~min}$ time intervals during the previous 1.5 days. As a measure for the convective influence we used the total amount of time an air parcel's temperature traced along its back trajectory was higher than the brightness temperature of the corresponding satellite pixels. The results show that the aircraft was flying along the border of a region with strong convective influence confirming our hypothesis of mixing with tropospheric air. The fraction of the introduced tropospheric air has been calculated by a mass balance calculation based on the $\mathrm{CO}$ measurements to lie between 5 and $20 \%$ and the expected $\mathrm{NO}_{\mathrm{y}}$ mixing ratios in the tropospheric air between about 6 and 10 ppbv. As the $\mathrm{CO}$ mixing ratios were hardly enhanced, the source of the elevated $\mathrm{NO}_{\mathrm{y}}$ is assumed to be production by lightning. In fact, high lightning activity has been registered in the convective cells over the western Mediterranean. However, the observed enhancement in $\mathrm{NO}_{\mathrm{y}}$ is approximately one order of magnitude higher than expected from a rough estimate based on the total number of lightning strokes, the total mass of air affected by the lightning, and typical values for NO-production per lightning stroke taken from the literature. This reflects the high uncertainty range in the made assumptions as well as in the used NO-production rate per lightning stroke.

An analysis of forward trajectories started from an area inside the stratospheric streamer for which a strong convective influence was calculated shows that $97 \%$ of these air parcels remain in the lowermost stratosphere during the following 10 days. This suggests that the convective injection of air with elevated mixing ratios of $\mathrm{NO}_{\mathrm{y}}$ and $\mathrm{H}_{2} \mathrm{O}$ may have had a considerable impact on the chemistry and radiative properties of this region. These findings support recent model studies by Wang (2003) and Mullendore (personal communication, 2003) showing that the breaking of gravity waves at the top of deep convective systems in mid-latitudes can cause injection of water vapor and other tropospheric tracers into the lowermost stratosphere in the form of plumes well above the thunderstorm anvils. Airborne measurement campaigns with high reaching aircraft especially designed to investigate the environment well above the anvils of the convective systems will be needed to validate the impact on tracer distributions predicted by these models. 
Acknowledgements. We gratefully acknowledge the excellent work of the firm enviscope $\mathrm{GmbH}$, Frankfurt (Germany), and the expert support of the personnel of GFD (Gesellschaft für Flugzieldarstellung), Hohn (Germany), for the implementation of the measurement campaigns. The project SPURT has been funded by the German BMBF (Bundesministerium für Bildung und Forschung) and the $\mathrm{NO}_{\mathrm{y}}$-measurements supported by the SNF (Schweizerischer Nationalfonds).

Edited by: A. Volz-Thomas

\section{References}

Beuermann, J., Konopka, P., Brunner, D., Bujok, O., Günther, O., McKenna, D. S., Lelieveld, J., Müller, R., and Schiller, C.: Highresolution measurements and simulation of stratospheric and tropospheric intrusions in the vicinity of the polar jet stream, Geophys. Res. Lett., 29, doi:10.29/2001GL014162, 2002.

Bradshaw, N. G., Vaughan, G., Busen, R., Garcelon, S., Jones, R., Gardiner, T., and Hacker, J.: Generation of layering in the lower stratosphere by a breaking Rossby wave, J. Geophy. Res., 107, doi:10.1029/2002JD002086, 2002.

Brasseur, G. and Solomon, S.: Aeronomy of the Middle Atmosphere, D. Reidel, Norwell, Mass., 452, 1986.

Bregman, A., van Velthoven, P. F. J., Wienhold, F., Fischer, H., Zenker, T., Waibel, A., Frenzel, A., Arnold, F., Harris, G. W., Bolder, M. J. A., and Lelieveld, J.: Aircraft measurements of $\mathrm{O}_{3}, \mathrm{HNO}_{3}$, and $\mathrm{N}_{2} \mathrm{O}$ in the Arctic lower stratosphere during the Stratosphere-Troposphere Experiment by Aircraft Measurements (STREAM) 1, J. Geophys. Res., 100, (D6), $11245-$ $11260,1995$.

Brunner, D., Staehelin, J., and Jeker, D.: Large-scale nitrogen oxide plumes in the tropopause region and implications for ozone, Science, 282, 1305-1308, 1998.

Dessler, A. E., Hintsa, E. J., Weinstock, E. M., Anderson, J. G., and Chan, K. R.: Mechanisms controlling water vapor in the lower stratopsphere: "A tale of two stratospheres", J. Geophys. Res. 100, 23 167-23 172, 1995.

Dethof, A., O'Neill, A., and Slingo, J.: Quantification of the isentropic mass transport across the dynamical tropopause, J. Geophys. Res., 105, 12 279-12 293, 2000.

Drapcho, D. L., Sisterson, D., and Kumar, R.: Nitrogen fixation by lightning activity in a thunderstorm, Atmos. Environ., 17, 729734, 1983.

Fahey, D. W., Eubank, C. S., Hubler, G., and Fehsenfeld, F. C.: Evaluation of a catalytic reduction technique for the measurement of total reactive odd-nitrogen $\mathrm{NO}_{\mathrm{y}}$ in the atmosphere, J. Atmos. Chem., 3, 435-468, 1985.

Fischer, H., Waibel, A., Welling, M., Wienhold, F.-G., Zenker, T., Crutzen, P. J., Arnold, F., Bürger, U., Schneider, J., Bregman, A., Lelieveld, J., and Siegmund, P. C.: Observations of high concentrations of total reactive nitrogen $\left(\mathrm{NO}_{\mathrm{y}}\right)$ and nitric acid $\left(\mathrm{HNO}_{3}\right)$ in the lower Arctic stratosphere during the StratosphereTroposphere Experiment by Aircraft Measurements (STREAM) II campaign in February 1995, J. Geophys. Res., 102, 23 559$23571,1997$.

Fischer, H., Wienhold, F.-G., Hoor, P., Bujock, O., Schiller, C., Siegmund, P., Ambaum, M., Scheeren, H. A., and Lelieveld, J.:
Tracer correlations in the northern high latitude lowermost stratosphere: Influence of cross-tropopause mass exchange, Geophys. Res. Lett., 27, (1), 97-100, 2000.

Fischer, H., Brunner, D., Harris, G. W., Hoor, P., Lelieveld, J., McKenna, D. S., Rudolph, J., Scheeren, H. A., Siegmund, P., Wernli, H., Williams, J., and Wong, S.: Synoptic tracer gradients in the upper troposhpere over central Canada during the Stratosphere-Troposphere Experiments by Aircraft Measurements 1998 summer campaign, J. Geophys. Res., 107, D8, 4064, doi:10.1029/2000JD000312, 2002.

Fischer, H., de Reus, M., Traub, M., Williams, J., Lelieveld, J., de Gouw, J., Warneke, C., Schlager, H., Minikin, A., Scheele, R., and Siegmund, P.: Deep convective injection of boundary layer air into the lowermost stratosphere at midlatitudes, Atmos. Chem. Phys., 3, 739-745, 2003.

Forster, P. M. de F. and Shine, K. P.: Radiative forcing and temperature trends from stratospheric ozone changes, J. Geophys. Res., 102, 10 841-10 857, 1997.

Frei, C., Christensen, J. H., Deque, M., Jacob, D., Jones, R. G., and Vidale, P. L.: Daily precipitation statistics in regional climate models: Evaluation and intercomparison for the European Alps, J. Geophys. Res., 108, D3, 4124, doi:10.1029/2002JD002287, 2003.

Fromm, M., Alfred, J., Hoppel, K., Hornstein, J., Bevilacqua, R., Shettle, E., Servranckx, R., Li, Z., and Stocks, B.: Observations of boreal forest fire smoke in the stratosphere by POAM III, SAGE II, and lidar in 1998, Geophys. Res. Lett., 27, 14071410, 2000.

Hoerling, M. P., Schaack, T. K., and Lenzen, A. J.: A global analysis of stratospheric-tropospheric exchange during northern winter, Mon. Weather Rev., 121, 162-172, 1993.

Hoinka, K. P., Reinhardt, M. E., and Metz, W.: North Atlantic air traffic within the lower stratosphere: cruising times and corresponding emissions, J. Geophys. Res., 98, 23 113-23 131, 1993.

Holton, J. R., Haynes, P. H., McIntyre, M. E., Douglass, A. R., Rood, R. B., and Pfister, L.: Stratosphere-troposphere exchange, Rev. Geophys., 33, 4, 403-439, 1995.

Hoor, P., Fischer, H., Lange, L., and Lelieveld, J.: Seasonal variations of a mixing layer in the lowermost stratosphere as identified by the $\mathrm{CO}-\mathrm{O}_{3}$ correlation from in situ measurements, J. Geophys. Res., 107, D5-D6, 4044, doi:10.1029/2000JD000289, 2002.

Hoor, P., Gurk, C., Brunner, D., Hegglin, M. I., Wernli, H., and Fischer, H.: Seasonality and extent of extratropcial TST derived from in-situ CO measurements during SPURT, Atmos. Chem. Phys. Discuss., 4, 1691-1726, 2004.

Huntrieser, H., Schlager, H., Feigl, C., and Höller, H.: Transport and production of $\mathrm{NO}_{\mathrm{x}}$ in electrified thunderstorms: Survey of previous studies and new observations at midlatitudes, J. Geophys. Res., 103, 28 247-28 264, 1998.

IPCC (Intergovernmental Panel on Climate Change): Aviation and the globale atmosphere, edited by Penner, J. E., Lister, D. H., Griggs, D. J., Dokken, D. J., and McFarland, M., Cambridge University Press, New York, 29-64, 1999.

IPCC (Intergovernmental Panel on Climate Change): Climate Change 2001, The Scientific Basis, edited by Houghton, J. T., Ding, Y., Griggs, D. J., Noguer, M., van der Linden, P. J., Dai, X., Maskell, K., and Johnson, C. A., Cambridge University Press, New York, 353-416, 2001. 
Jeker, P. D., Pfister, L., Thompson, A. M., Brunner, D., Boccippio, D. J., Pickering, K. E., Wernli, H., Kondo, Y., and Staehelin, J.: Measurements of nitrogen oxides at the tropopause: Attribution to convection and correlation with lightning, J. Geophys. Res., 105, 3679-3700, 2000.

Kessler, E.: On the distribution and continuity of water substance in atmospheric circulation models, Meteor. Monographs, 10, American Meteorological Society, Boston, MA, 1969.

Koch, G., Wernli, H., Staehelin, J., and Peter, Th.: A Lagrangian analysis of stratospheric ozone variability and long-term trends above Payerne (Switzerland) during 1970-2001, J. Geophys. Res., 107, D19, 4373, doi:10.1029/2001JD001550, 2002.

Koike, M., Kondo, Y., Takegawa, N., Lefevre, F., Ikeda, H., Irie, H., Hunton, H. D. E., Viggiano, A. A., Miller, T. M., Ballenthin, J. O., Sachse, G. W., Anderson, B. E., Avery, M., and Masui, Y.: Redistribution of reactive nitrogen in the Arctic lower stratosphere in the 1999/2000 winter, J. Geophys. Res., 107, D20, 8275, doi:10.1029/2001JD001089, 2002.

Lacis, A. A., Wuebbles, D. J., and Logan, J. A.: Radiative forcing of climate by changes in the vertical distribution of ozone, $\mathrm{J}$. Geophys. Res., 95, 9971-9981, 1990.

Lange, L., Hoor, P., Helas, G., Fischer, H., Brunner, D., Scheeren, B., Williams, J., Wong, S., Wohlfrom, K.-H., Arnold, F., Ström, J., Krejci, R., Lelieveld, J., and Andreae, M. O.: Detection of lightning-produced NO in the midlatitude upper troposphere during STREAM 1998, J. Geophys. Res., 106, 27 777-27 785, 2001.

Lange, L., Fischer, H., Parchatka, U., Gurk, C., Zenker, T., and Harris, G. W.: Characterization and application of an externally mounted catalytic converter for aircraft measurements of $\mathrm{NO}_{\mathrm{y}}$, Rev. Sci. Instrum., 73, 8, 3051-3057, 2002.

Lee, D. S., Köhler, I., Grobler, E., Roherer, F., Sausen, R., GallardoKlenner, L., Olivier, J. G. J., Dentener, F. J., and Bouwman, A. F.: Estimations of globale $\mathrm{NO}_{\mathrm{X}}$ emissions and their uncertainties, Atmos. Environ., 31, (12), 1735-1749, 1997.

Levizzani, V. and Setvak, M.: Multispectral, high-resolution satellite observations of plumes on top of convective storms, J. Atmos. Sci., 53, 3, 361-369, 1996.

Lin, Y.-L., Farley, R. D., and Orville, H. D.: Bulk parameterization of the snow field in a cloud model, J. Clim. Appl. Meteor., 22, 1065-1092, 1983.

Mottaghy, D.: Ozonmessungen in der unteren Stratosphäre (in German), Diploma thesis, RWTH Aachen in cooperation with Forschungszentrum Jülich, October, 2001.

Murphy, D., Fahey, D., Proffitt, M., Liu, S., Chan, K., Eubank, C., Kawa, S., and Kelly, K.: Reactive nitrogen and its correlation with ozone in the lower stratosphere and upper troposphere, J. Geophys. Res., 98, D5, 8751-8773, 1993.

Oltmans, S. J. and Hofmann, D. J.: Increase in lower-stratospheric water vapour at a mid-latitude Northern hemisphere site from 1981 to 1994, Nature, 374, 146-149, 1995.

Pepler, S. J., Vaughan, G., and Hooper, D. A.: Detection of turbulence around jet streams using a VHF radar, Q. J. R. Meteorol. Soc., 124, 447-462, 1998.

Pickering, K. E., Wang, Y., Tao, W.-K., Price, C., and Müller, J.F.: Vertical distributions of lightning $\mathrm{NO}_{\mathrm{x}}$ for use in regional and global chemical transport models, J. Geophys. Res., 103, 31203 $31216,1998$.

Poulida, O., Dickerson, R. R., and Heymsfield, A.: Stratospheretroposphere exchange in a midlatitude mesoscale convective complex: 1. Observations, J. Geophys. Res., 101, 6823-6863, 1996.

Ray, E. A., Moore, F. L., Elkins, J. W., Dutton, G. S., Fahey, D. W., Vömel, H., Oltmans, S. J., and Rosenlof, K. H.: Transport into the Northern Hemisphere lowermost stratosphere revealed by in situ tracer measurements, J. Geophys. Res., 104, (D21), 26565 $26580,1999$.

Ridley, B. and Howlett, L.: An instrument for NO measurements in the stratosphere, Rev. Sc. Instrum., 45, 742-746, 1974.

Schoeberl, M. R. and Newman, P. A.: A multiple-level trajectory analysis of vortex filaments, J. Geophys. Res., 100, $25801-$ $25815,1995$.

Schumann, U.: The impact of nitrogen oxides emissions from the aircraft upon the atmosphere at flight altitudes - results from the AERONOX project, Atmos. Environ., 31, 1723-1733, 1997.

Stohl, A., Huntrieser, H., Richter, A., Beirle, S., Cooper, O., Eckhardt, S., Forster, C., James, P., Spichtinger, N., Wenig, M., Wagner, T., Burrows, J., and Platt, U.: Rapid intercontinental air pollution transport associated with a meteorological bomb, Atmos. Chem. Phys., 3, 969-985, 2003.

Ström, J., Fischer, H., Lelieveld, J., and Schröder, F.: In situ measurements of microphysical porperties and trace gases in two cumulonimbus anvils over Western Europe, J. Geophys. Res., 104, 21 221-12 226, 1999.

Thomas, W., Baier, F., Erbertseder, T., and Kästner, M.: Analysis of the Algerian severe weather event in November 2001 and its impact on ozone and nitrogen dioxide distributions, Tellus, 55B, 993-1006, 2003.

Tiedtke, M.: A comprehensive mass flux scheme for cumulus parameterization in large-scale models, Mon. Wea. Rev., 117, 1779-1800, 1989.

Vidale, P. L., Lüthi, D., Frei, C., Seneviratne, S. I., and Schär, C.: Predictability and uncertainty in a regional climate model, J. Geophys. Res., 108, D18, 4586, doi:10.1029/2002JD002810, 2003.

Waibel, A. E., Fischer, H., Wienhold, F.-G., Siegmund, P. C., Lee, B., Ström, J., Lelieveld, J., and Crutzen, P. J.: Highly elevated carbon monoxide concentrations in the upper troposphere and lowermost stratosphere at northern midlatitudes during the STREAM II summer campaign in 1994, Chemosphere: Global Change Science, 1, 233-248, 1999.

Wang, P. K.: Moisture plumes above thunderstorm anvils and their contributions to cross-tropopause transport of water vapor in midlatitudes, J. Geophys. Res., 108, D6, 4194, doi:10.1029/2002JD002581, 2003.

Weinheimer, A. J., Walega, J. G., Ridley, B. A., Sachse, G. W., Anderson, B. E., and Collins Jr., J. E.: Stratospheric $\mathrm{NO}_{\mathrm{y}}$ measurements on NASA DC-8 during AASE II, Geophys. Res. Lett., 20, 2563-2566, 1993.

Weinheimer, A. J., Walega, J. G., Ridley, B. A., Gary, B. L., Blake, D. R., Blake, N. J., Rowland, F. S., Sachse, G. W., Anderson, B. E., and Collins, J. E.: Meridional distribution of $\mathrm{NO}_{\mathrm{x}}, \mathrm{NO}_{\mathrm{y}}$, and other species in the lower stratosphere and upper troposphere during AASE-II, Geophys. Res. Lett., 21, 23, 2583-2586, 1994.

Wernli, H. and Bourqui, M.: A Lagrangian "1-year climatology" of (deep) cross tropopause exchange in the extratropical Northern Hemisphere, J. Geophys. Res., 107, D1-D2, 4021, doi:10.1029/2001JD000812, 2002 
Wernli, H. and Davies, H. C.: A Lagrangian-based analysis of extratropical cyclones, I. The method and some applications, Q. J. R. Meteorol. Soc., 123, 467-489, 1997.

Ziereis, H., Schlager, H., Fischer, H., Feigl, C., Hoor, P., Marquardt, R., and Wagner, V.: Aircraft measurements of tracer correlations in the Arctic subvortex region during the Polar Stratospheric Aerosol Experiment (POLSTAR), J. Geophys. Res., 105, D19, 24 305-24 313, 2000.

Zierl, B. and Wirth, V.: The influence of radiation on tropopause behavior and stratosphere-troposphere exchange in an upper tropospheric anticylone, J. Geophys. Res., 102, D20, 23 883-23 894, 1997.
Zöger, M., Afchine, A., Eicke, N., Gerhards, M. T., Klein, E., McKenna, D. S., Morschel, U., Schmidt, U., Tan, V., Tuitjer, F., Woyke, T., and Schiller, C.: Fast in situ stratospheric hygrometer: A new family of balloon-borne and airborne Lyman-alpha photofragment fluorescence hygrometers, J. Geophys. Res., 104, 1807-1816, 1999. 